Landslide Hazards Program

\title{
Preliminary Assessment of the Wave Generating Potential from Landslides at Barry Arm, Prince William Sound, Alaska
}

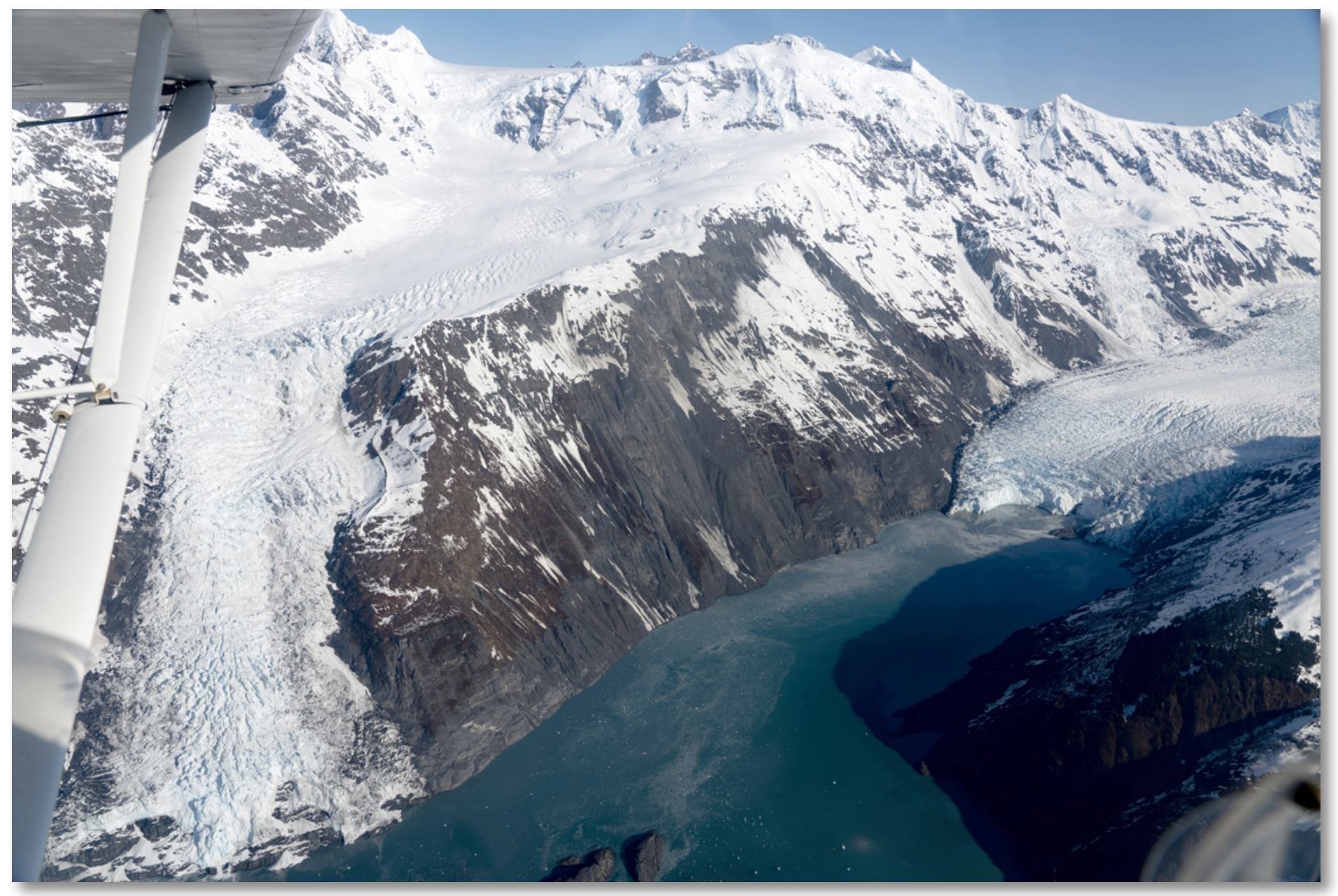

Open-File Report 2021-1071 
Cover. Barry Arm of Harriman Fjord, Prince William Sound, Alaska (Photograph from Christian Zimmerman, U.S. Geological Survey). 


\section{Preliminary Assessment of the Wave Generating Potential from Landslides at Barry Arm, Prince William Sound, Alaska}

By Katherine R. Barnhart, Ryan P. Jones, David L. George, Jeffrey A. Coe, and

Dennis M. Staley

Landslide Hazards Program

Open-File Report 2021-1071 


\section{U.S. Geological Survey, Reston, Virginia: 2021}

For more information on the USGS - the Federal source for science about the Earth, its natural and living resources, natural hazards, and the environment—visit https://www.usgs.gov or call 1-888-ASK-USGS.

For an overview of USGS information products, including maps, imagery, and publications, visit https://store.usgs.gov/.

Any use of trade, firm, or product names is for descriptive purposes only and does not imply endorsement by the U.S. Government.

Although this information product, for the most part, is in the public domain, it also may contain copyrighted materials as noted in the text. Permission to reproduce copyrighted items must be secured from the copyright owner.

Suggested citation:

Barnhart, K.R., Jones, R.P., George, D.L., Coe, J.A., and Staley, D.M., 2021, Preliminary assessment of the wave generating potential from landslides at Barry Arm, Prince William Sound, Alaska: U.S. Geological Survey Open-File Report 2021-1071, 28 p., https://doi.org/10.3133/ofr20211071.

Associated data for this publication:

Barnhart, K.R., Jones, R.P., George, D.L., Coe, J.A., Staley, D.A., 2021, Select model results from simulations of hypothetical rapid failures of landslides into Barry Arm Fjord, Prince William Sound, Alaska: U.S. Geological Survey data release, https://doi.org/10.5066/PgXVJDNP.

ISSN 2331-1258 (online 


\section{Contents}

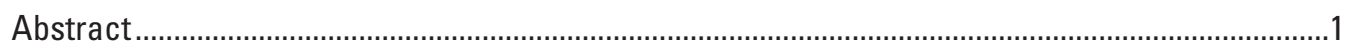

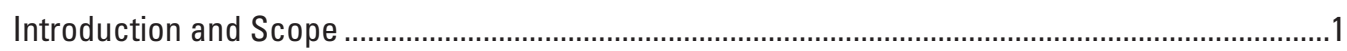

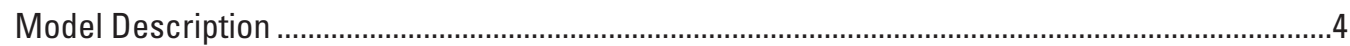

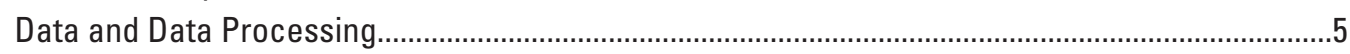

Landslide Source Characteristics and Scenario Design ...........................................................

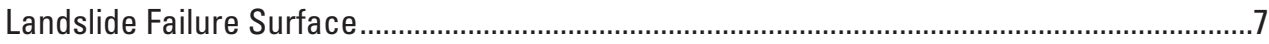

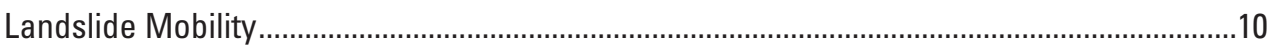

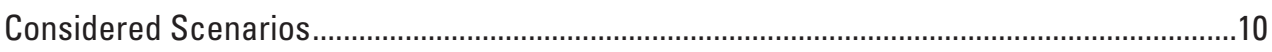

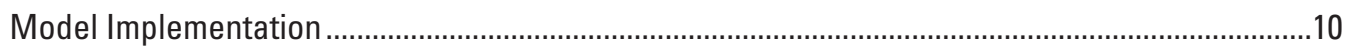

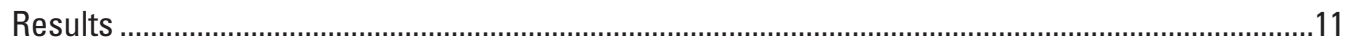

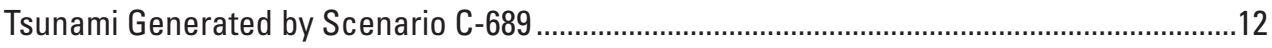

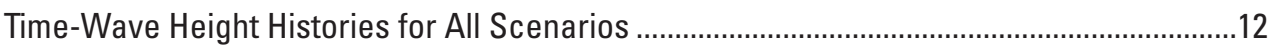

Maximum Wave Height Generated by Scenario C-689 ..........................................................17

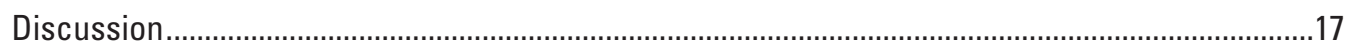

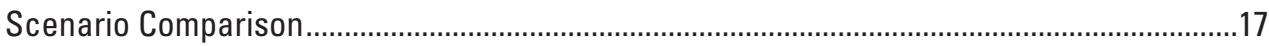

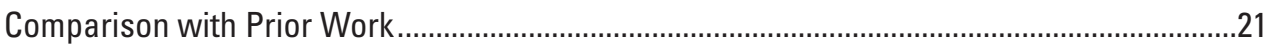

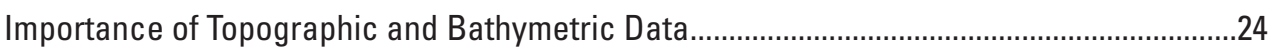

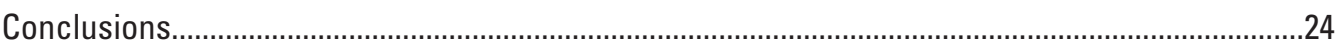

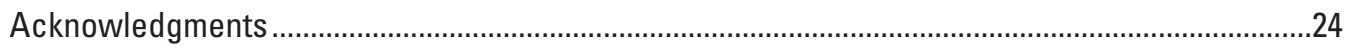

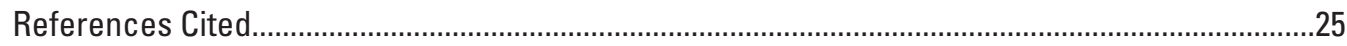

\section{Figures}

1. Map of $A$, Prince William Sound, Alaska, and $B$, the region between Whittier, Alaska, and the landslide source area............................................................................

2. Map of $A$, the region between Barry Arm and Whittier, Alaska, and $B$, inset showing the location of the Barry Arm landslides...........................................................

3. Map showing extent of topographic and bathymetric data sources ...............................6

4. Maps of the landslide depth to failure surface for $A$, the smaller landslide volume and $B$, the larger landslide volume. Example transect locations are shown in $C$ as dashed lines, here spaced 400 meters apart. The yellow polygon in $C$ represents the main body of Landslide $A$, and the solid black line goes through the centroid (white dot) at an orientation perpendicular to the downslope direction. The transect shown in $D$ is from the thick dashed line in $A-C$......8

5. Maps of landslide material extent for the first 4 minutes of simulated time for $A$, scenario C-290, $B$, scenario NC-290, $C$, scenario C-689, and $D$, scenario NC-689......12

6. Cross section through Barry Arm fjord from the landslide source region into Port Wells.

7. Graphs showing wave height as a function of simulated time for each of the four considered scenarios at eight hypothetical gage locations indicated in figure 2 .

8. Graphs showing wave height as a function of simulated time for each of the four considered scenarios at eight hypothetical gage locations indicated in figure $2 B$. 
9. Maps of $A-D$, maximum wave height for the larger, contractive, more mobile scenario $\mathrm{C}-689$, which produces the largest tsunami

10. Maps of $A-D$, tsunami travel time for the larger, contractive, more mobile C-689 scenario which produces the largest tsunami. Extent of panels $B-D$ shown in figure 1 .

11. Maps of $A-D$, time of peak wave height for the larger, contractive, more mobile C-689 scenario which produces the largest tsunami.

12. Graph showing approximate volume of fjord water displaced by landslide material for each of the four considered scenarios

13. Graphs showing $A$, Wave height, $B$, velocity, and $C$, momentum for the first minute of simulation taken from the location labeled by the white star in figure $2 B$ (location given in table 3 )

14. Maps showing time evolution of the wave generated by the larger, contractive, more mobile scenario C-689

\section{Tables}

1. Summary of four considered scenarios including key simulation input parameter values

2. Summary of depth and volume of the two landslide geometries and adjacent waterbody

3. Hypothetical gage locations shown in figure 2. Easting and northing coordinates are in North American Datum of 1983 (NAD 83) Universal Transverse Mercator (UTM) Zone 6 N (European Petroleum Survey Group [EPSG] 26906).

\section{Conversion Factors}

International System of Units to U.S. customary units

\begin{tabular}{lcl}
\hline \multicolumn{1}{c}{ Multiply } & By & \multicolumn{1}{c}{ To obtain } \\
\hline & Length & \\
centimeter $(\mathrm{cm})$ & 0.3937 & inch (in.) \\
meter $(\mathrm{m})$ & 3.281 & foot (ft) \\
kilometer $(\mathrm{km})$ & 0.6214 & mile (mi) \\
kilometer $(\mathrm{km})$ & 0.5400 & mile, nautical (nmi) \\
meter $(\mathrm{m})$ & 1.094 & yard (yd) \\
& Area & acre \\
square meter $\left(\mathrm{m}^{2}\right)$ & 0.0002471 & square foot (ft $\left.{ }^{2}\right)$ \\
square meter $\left(\mathrm{m}^{2}\right)$ & 10.76 & \\
& Volume & gallon (gal) \\
cubic meter $\left(\mathrm{m}^{3}\right)$ & 264.2 & million gallons $(\mathrm{Mgal})$ \\
cubic meter $\left(\mathrm{m}^{3}\right)$ & 0.0002642 & cubic foot (ft $\left.{ }^{3}\right)$ \\
cubic meter $\left(\mathrm{m}^{3}\right)$ & 35.31 & cubic yard (yd $\left.{ }^{3}\right)$ \\
cubic meter $\left(\mathrm{m}^{3}\right)$ & 1.308 & acre-foot (acre-ft) \\
cubic meter $\left(\mathrm{m}^{3}\right)$ & 0.0008107 &
\end{tabular}




\section{Datum}

Vertical coordinate information is referenced to the mean higher high water (MHHW) at National Oceanic and Atmospheric Administration (NOAA) Station 9454949 (Whittier, Alaska).

Horizontal coordinate information is referenced to the North American Datum of 1983 (NAD 83). Universal Transverse Mercator Zone 6 North is used.

Altitude and height, as used in this report, refer to distance above the vertical datum.

\section{Abbreviations}

DGGS Alaska Division of Geology \& Geophysical Surveys

EPSG European Petroleum Survey Group

InSAR interferometric synthetic aperture radar

MHHW mean higher high water

MLLW mean lower low water

NAD 83 North American Datum of 1983

NAVD 88 North American Vertical Datum of 1988

NOAA National Oceanic and Atmospheric Administration 



\title{
Preliminary Assessment of the Wave Generating Potential from Landslides at Barry Arm, Prince William Sound, Alaska
}

\author{
By Katherine R. Barnhart, Ryan P. Jones, David L. George, Jeffrey A. Coe, and Dennis M. Staley
}

\section{Abstract}

We simulated the concurrent rapid motion of landslides on an unstable slope at Barry Arm, Alaska. Movement of landslides into the adjacent fjord displaced fjord water and generated a tsunami, which propagated out of Barry Arm. Rather than assuming an initial sea surface height, velocity, and location for the tsunami, we generated the tsunami directly using a model capable of simulating the dynamics of both water and landslide material. The fjord below most of the landslide source area was occupied by the Barry Glacier until about 2012; therefore, our direct simulation of tsunami generation by landslide motion required new topographic and bathymetric data, which was collected in 2020. The topographic data also constrained landslide geometries and volumes. We considered four scenarios based on two landslide volumes and two landslide mobilities - a more mobile, contractive landslide and a less mobile, noncontractive landslide. The larger of the two volumes is $689 \times 10^{6}$ cubic meters $\left(\mathrm{m}^{3}\right)$ - larger than the volume estimate in a previous study - and reflects the largest plausible volume given current observational data. The considered scenario that generated the largest wave heights resulted in forecast wave heights of over 200 meters $(\mathrm{m})$ in the northern part of Barry Arm, adjacent to the landslide source area and runup on the opposite fjord wall in excess of $500 \mathrm{~m}$. Simulated wave heights in excess of $5 \mathrm{~m}$ in southern Barry Arm and in Harriman Fjord occurred within 10-15 minutes (min) of landslide motion. The simulated tsunami reached Whittier, Alaska, approximately 20 min after initial rapid landslide motion, with peak heights of just over $2 \mathrm{~m}$ in Passage Fjord, $500 \mathrm{~m}$ offshore Whittier, occurring 26 min after initial rapid motion. Time of peak wave heights was consistent with previous modeling. Although results are preliminary and can be refined with additional observations and analyses, they provide a refined assessment of the upper bound of the hazard presented by the Barry Arm landslides. The results herein support the National Oceanic and Atmospheric Administration's National Tsunami Warning Center mission to detect, forecast, and warn for tsunamis in Alaska.

\section{Introduction and Scope}

When situated upslope of waterbodies, landslides have the potential to generate a tsunami by rapidly moving into the waterbodies and displacing water. This poses a hazard to nearby populations, infrastructure, and marine traffic. There are multiple recent instances of tsunamigenic landslides in steep maritime terrain in the Arctic and subarctic. These events are particularly problematic in areas that have experienced rapid glacial retreat, as (1) debuttressing of and (or) thermomechanical damage to steep valley sides may increase the susceptibility of valley walls to rapid landslide motion, and (2) rapid glacial retreat may increase the likelihood of landslide runout into open water rather than onto glacial ice that would have been present prior to glacial retreat. Examples of large tsunamigenic landslides in recently deglaciated terrain include July 9, 1958, Lituya Bay, Alaska (Miller, 1960a, b; Ward and Day, 2010); April 27, 1975, Kitimat, British Columbia (Kirby and others, 2016); October 17, 2015, Taan Fjord, Alaska (George and others, 2017; Haeussler and others, 2018; Higman and others, 2018); and June 17, 2017, Karrat Fjord, Greenland (Bessette-Kirton and others, 2017; Poli, 2017; Gauthier and others, 2018).

In spring 2020, a citizen scientist identified a large, potentially tsunamigenic landslide in Barry Arm (figs. 1 and 2), a recently deglaciated fjord in Prince William Sound, Alaska (Johnson, 1916; Dai and others, 2020). Here, the northwest flank of the fjord side wall has destabilized into at least three large, slow-moving landslides (fig. 2; Dai and others, 2020; Schaefer and others, 2020; Coe and others, 2021). Evidence for motion at the largest landslide (named Landslide A) extends back to 1957, with more rapid movement between 2010 and 2017 coincident with the retreat of the Barry Glacier calving front (Dai and others, 2020). During 2020, remote interferometric synthetic aperture radar (InSAR) monitoring revealed seasonally isolated movement of Landslide A of about 17 centimeters $(\mathrm{cm})$ between September 23 and October 17 (Schaefer and others, 2020). Based on strike slip and oblique slip faults located within Landslide A, Coe and others (2021) subdivided Landslide A into three kinematic elements (fig. 2; the Prow, Core, and Tail). The kinematic 
element boundaries reflect past deformational history and may change based on future deformation. The second landslide, Landslide B or the Wedge, is located up valley to the northeast of Landslide A. It was identified during InSAR analysis in summer 2020 and confirmed as an active landslide by InSAR deformation and structure mapping (Schaefer and others, 2020; Coe and others, 2021). The third landslide was identified based on differencing of June and October 2020 light detection and ranging (lidar) data by the Alaska Division of Geology \& Geophysical Surveys (DGGS). This analysis revealed rapid movement of an area adjacent to Landslide A called the Kite (fig. 2) and a significant rockfall that mobilized as a rock avalanche from the headscarp of Landslide A (DGGS, 2021). The planimetric extent of Landslide A and the Kite are adjacent; however, the structural mapping (Coe and others, 2021) and lidar differencing (DGGS, 2021) indicate that these landslides moved independently in 2020. Although recent landslide kinematics are relatively well constrained, little is known about the potential for future rapid motion, landslide volumes, and timescale over which the hazard will persist.
For this preliminary report, we simulated the generation and propagation of a tsunami originating from the concurrent rapid motion of Landslides A and B and the Kite into the adjacent fjord water. Our primary goal was to advance our understanding of potential tsunamigenic landslide hazards for the Barry Arm landslides using a coupled landslide runout and wave propagation model. Our results support the National Oceanic and Atmospheric Administration (NOAA) National Tsunami Warning Center's mission to provide reliable detection, forecasting, and warning of tsunamis to protect life and property. Our methods advance upon existing work (for example, the tsunami modeling of Dai and others, 2020) through the direct treatment of landslide physics using the model D-Claw and incorporation of topographic and bathymetric data collected in 2020 (NOAA, 2020; Daanen and others, 2021). D-Claw is a depth-averaged, two-phase model capable of simulating motion of variable granular fluid mixtures, ranging from landslides to clear water, and has been used to simulate subaerial landslide tsunami generation (George and others, 2017). Rather than assume an initial location, wave height,
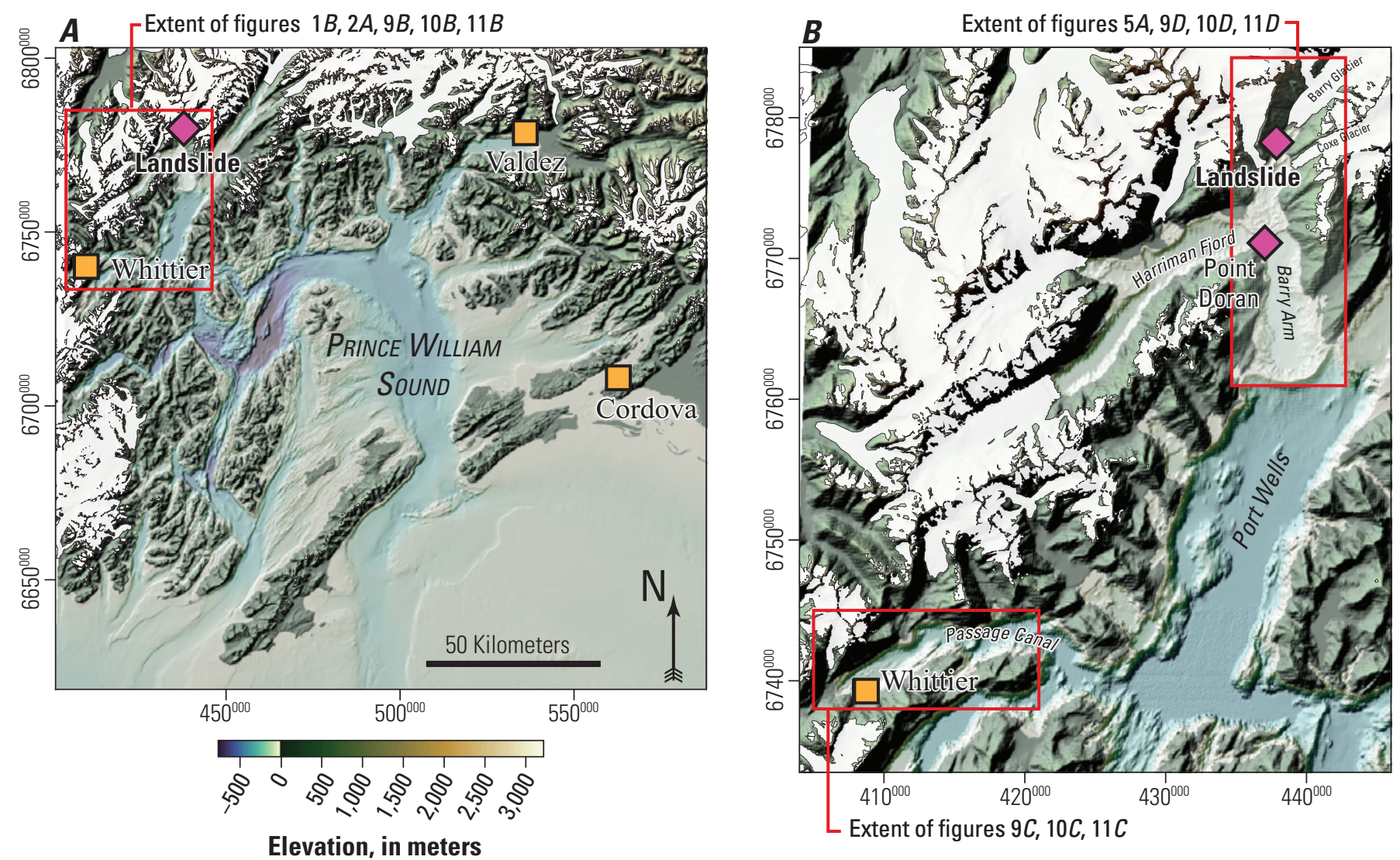

Figure 1. A, Prince William Sound, Alaska, and $B$, the region between Whittier, Alaska, and the landslide source area. Both maps indicate place names discussed in the text, and panel $A$ indicates the considered computational domain. Here and in subsequent figures, glacial extents indicated by white polygons reflect the Randolph Glacier Inventory version 6.0 (RGI Consortium, 2017). The extent of Barry Glacier in the inventory was modified to reflect its summer 2020 extent. Easting and northing coordinates are in North American Datum of 1983 (NAD 83) Universal Transverse Mercator (UTM) Zone 6 N (European Petroleum Survey Group [EPSG] code 26906). Hillshade vertical exaggeration (VE) equal to 3. 

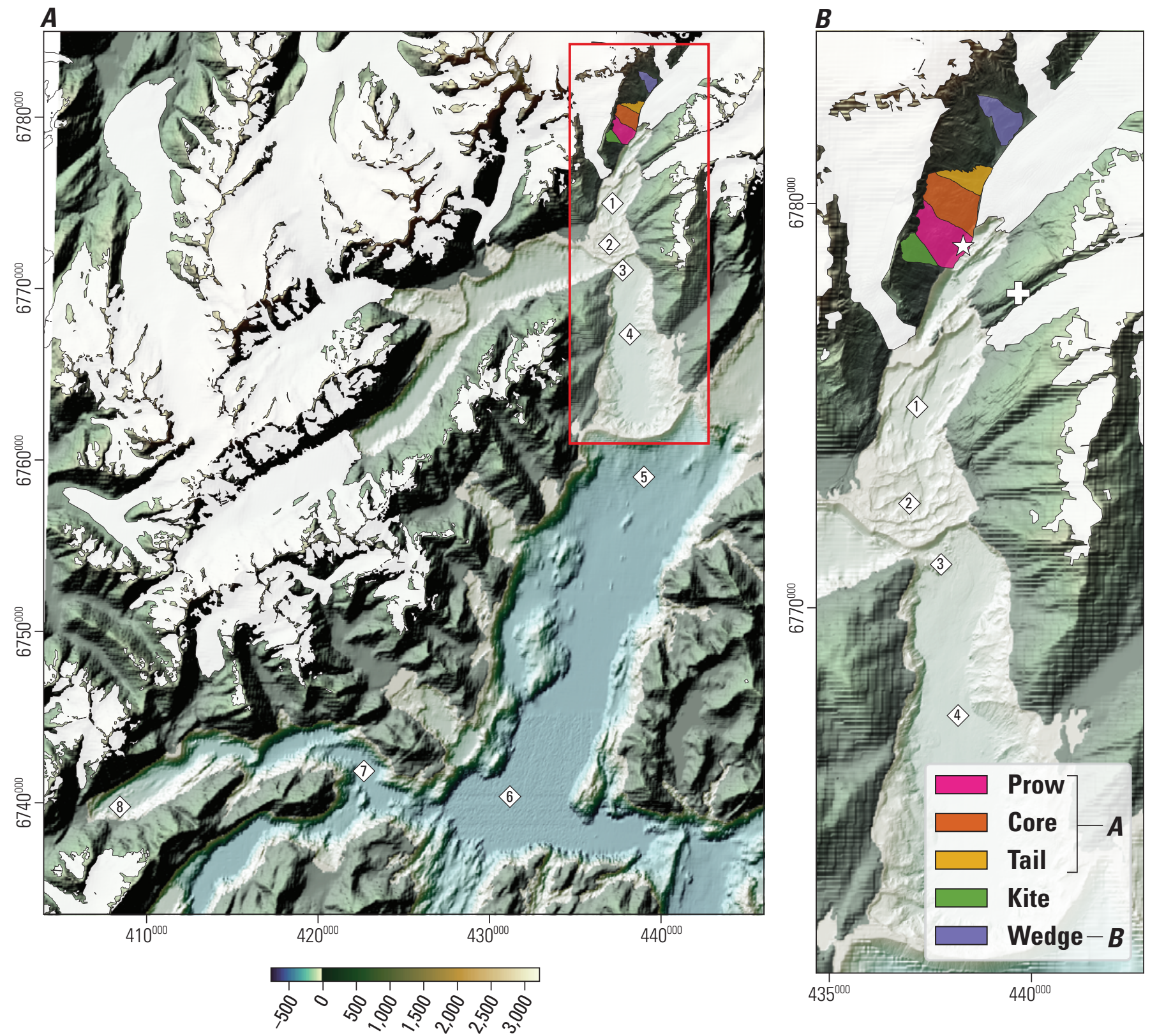

Elevation, in meters

Figure 2. $A$, the region between Barry Arm and Whittier, Alaska, and $B$, inset showing the location of the Barry Arm landslides. Extent of $B$ indicated by red box in $A$. Location and identification (ID) number of hypothetical gages discussed in the text indicated with white diamonds or white star (coordinates provided in table 3). Colored polygons indicate landslide kinematic elements as mapped by Coe and others (2021). Landslide A contains the Prow, Core, and Tail. Landslide B contains the Wedge. The Kite is an independent kinematic element identified by Coe and others (2021). The location of seismic station Barry Arm East (BAE) indicated with the white plus sign. Easting and northing coordinates are in North American Datum of 1983 (NAD 83) Universal Transverse Mercator (UTM) Zone 6 N (European Petroleum Survey Group (EPSG) code 26906). Hillshade vertical exaggeration (VE) equal to 3. 
and velocity for the tsunami, the use of D-Claw permits direct simulation of tsunami genesis from landslide motion into the fjord. Within, we consider only the case of all identified landslides rapidly moving together, two alternative landslide volumes constrained by observations of headscarp and toe angles, and two options for landslide mobility.

The larger of the two considered volumes represents the largest plausible volume, given current observational constraints. Additional observations may refine our understanding and could increase or decrease the estimated volume. Before this work was conducted, whether a landslide with material that is more mobile would produce a larger tsunami than a landslide with material is less mobile was not clear; accordingly, we considered both cases. Similarly, considering only the scenario in which all landslides rapidly move together is intended to represent the likely worst-case scenario that produces the largest waves. Whether other landslide geometries or rapid landslide motion sequences will produce a larger wave is uncertain. For example, the following are other plausible scenarios: a sequence in which movement of an identified landslide destabilizes an adjacent, previously stable area; complex landslide-water-glacier interactions below Landslide $\mathrm{B}$; or far-field tsunami-tidewater glacier interactions.

The newly available topographic and bathymetric data allow us to directly simulate the landslide and subsequent wave generation, rather than assume the magnitude of an initial wave. Our scenarios, topographic surface, and bathymetric surface are constrained by data collected after the preliminary modeling by Dai and others (2020), which simulated a series of hypothetical waves, generated not by landslide-water interaction, but as "hot start" initial wave conditions (more discussion of "hot start" initial conditions are discussed in "Model Description" section). We describe the approach of Dai and others (2020) and compare our results with theirs in the "Discussion" section.

Our results reflect a refinement on anticipated wave heights near the landslide, as well as in more distal locations in Prince William Sound, including at Passage Canal near the town of Whittier, Alaska.

\section{Model Description}

We use D-Claw, a depth-averaged model originally developed for dense granular flows such as landslides and debris flows. D-Claw simulates the coupled evolution of fluid and solid phases while satisfying mass and momentum conservation. The theoretical basis and numerical implementation are described in Iverson and George (2014) and George and Iverson (2014), respectively. D-Claw is related to the opensource GeoClaw software, which was originally developed for tsunami modeling (George, 2006; Berger and others, 2011; LeVeque and others, 2011; Mandli and others, 2016). It is a part of the Clawpack family of models developed for solving hyperbolic systems of equations (LeVeque, 2002).
D-Claw can simulate solid material and fluid mixtures that span high solid volume fraction (landslide material, for example, might have a solid volume fraction of 0.64 ) to low solid volume fraction (water has a solid volume fraction of 0.0 ). The model conceptualizes landslide material as fully saturated granular material. In this work, we discuss the mobility of this material-our use of this term followed Iverson and others (2015) and Iverson and George (2016) in considering the mobility of a landslide as the combination of its speed and runout distance. A major control on the mobility of material in D-Claw is the difference between the evolving solid volume fraction, $m$, and the evolving equilibrium critical state solid volume fraction, $m_{e q n}$, because the sign of $m-m_{e q n}$ controls whether material motion is contractive, resulting in a positive feedback in which pore pressure increases thereby reducing effective frictional resistance. The positive pore pressure feedback present in contractive material results in a more mobile landslide. In contrast, incipient motion of noncontractive material does not result in elevated pore pressure and reduced frictional resistance as readily. All else equal, a landslide composed of noncontractive material is less mobile.

In D-Claw, material of a user-specified spatially variable thickness, velocity, pore pressure, and solid volume fraction is initialized on top of a basal surface. Under a landslide, the basal surface represents the failure surface; under the ocean, it represents the seafloor; and elsewhere, it represents the topographic surface (for example, the surface of Barry Arm Glacier). D-Claw can support a time-variable basal surface (for example, to generate a coseismic tsunami). We did not use this capability in our application. When material is initialized without velocity (as was done in our application), the material will remain stationary if gravitational driving forces are balanced by the resisting forces of granular friction. If driving forces exceed resistance, the unstable material moves, converting potential energy into kinetic energy. Depending on the solid volume fraction, some of the energy is absorbed by granular friction.

After rapid downslope motion, granular material may come to rest at an angle that is lower than the angle of internal friction. To reflect this observation, we use a version of D-Claw recently extended to include the frictional hysteresis model of Rocha and others (2019) in which the basal friction angle ( $\varphi$ in Iverson and George, 2014) is reduced by an angle $\varphi_{\Delta}$ based on the Froude number. The implication of this extension is that the angle at which moving material with high solid volume fraction comes to rest is lower than the friction angle of static material $\varphi$.

In the absence of solid material, D-Claw's equations reduce to the nonlinear shallow-water equations, and GeoClaw solutions are reproduced. The shallow water equations are a commonly used approach for simulating coseismic tsunamis. Where water depths are shallower than a user-specified threshold, a Manning's n value friction coefficient is used to represent bottom friction. Higher-order dispersive terms, absent in the shallow water equations, are increasingly recognized to play a more significant role in the wave characteristics 
of landslide-generated tsunamis compared to coseismic ones (for example, see Fritz and others, 2004; Heller and Hager, 2011; Kirby and others, 2013; Løvholt and others, 2015). Previous work has applied dispersive Boussinesq-type, waterwave models to submarine landslide-generated tsunamis (for example, Lynett and Liu, 2002, 2005; Watts and others, 2003; Grilli and Watts, 2005; Geist and others, 2009; Zhou and Teng, 2010; Shi and others, 2012; Ma and others, 2013). Such a model may be necessary to more accurately resolve complex features like harbor currents and offshore wave interactions. However, our focus here is on the accuracy of the landslide motion, subsequent wave generation, and magnitude of the largest waves. Nevertheless, implementing a Boussinesq model with our initial waveform may reveal more detailed features of the far-field tsunami behavior.

Numerical simulations of subaerial landslide-generated tsunamis can be broadly grouped into four types (see the review by Yavari-Ramshe and Ataie-Ashtiani, 2016); all have limitations. A comparison of these approaches is discussed in George and others (2017), and we summarize the approaches here: (1) use of an independent landslide model to generate time-variable boundary conditions, subsequently coupled to a wave propagation model; (2) three dimensional (3D) multifluid models; (3) depth-averaged multilayer models; and (4) depthaveraged two-phase codes that can seamlessly simulate both the landslide and water-wave propagation via direct mass and momentum conservation (for example, D-Claw). Each option varies in its computational intensity, assumptions regarding the geometry of the landslide and the waterbody, and representation of horizontal/vertical mass and momentum exchange.

Any approach that does not directly simulate a landslide must make assumptions regarding how the landslide will behave and how this behavior will translate into an initial waveform. This initial waveform - represented by spatially distributed values for sea surface height and velocity—is then placed into the simulation domain. When the simulation begins, the wave propagates based on the governing equations. Because such an approach initializes a simulation with a preformed wave, it has been called a "hot start" initial condition (Grilli and others, 2013). One example of this type of approach is the use of a landslide impact model that was used to generate an initial waveform for the Tidal Inlet landslide by Wieczorek and others (2007). In contrast, use of a model like D-Claw, which can directly simulate a wide range of landside dynamics, means that we need not make these assumptions. Instead, the landslide material evolves under its governing equations, exchanges mass and momentum with the ocean water, and thereby generates a tsunami.

George and others (2017) demonstrated the feasibility and validity of using D-Claw to simulate a tsunamigenic landslide at Tyndall Glacier, which generated a wave that propagated into Taan Fjord - a comparable situation to Barry Arm. Accordingly, we summarize their initialization strategy and their results. They initialized the simulation with a static dense granular-fluid mixture in the landslide source zone and still water in Taan Fjord and Icy Bay. The approach used to initiate landslide motion was to initialize the pore pressure in the landslide material at hydrostatic pressure. When the simulation commenced, intergranular friction was insufficient to resist the driving force of gravity, and the landslide material rapidly moved downslope, impacting the still water and generating waves via direct momentum exchange and mass displacement. As discussed by George and others (2017), this approach was beneficial in that no coupling was needed to translate landslide motion into wave generation as is appropriate when the depth and length scales of the landslide and waterbody are similar (a characteristic that holds true for Barry Arm). George and others (2017) assessed the validity of their simulation at Taan Fjord by comparing simulated inundation limits and normalized difference vegetation index (NDVI) values from Landsat 8 Operational Land Imager images. Simulated inundation matches observed areas with negative NDVI, which indicate areas of vegetation removal. These areas of negative NDVI are qualitatively consistent with the inundation extent mapped in the field and presented in the subsequent publication of Higman and others (2018).

\section{Data and Data Processing}

The subaerial lidar and submarine bathymetric data acquired in 2020 were necessary to simulate landslide motion directly into the fjord (fig. 3). Prior to the 2020 bathymetric survey, the most recent bathymetric data were from 1992 (NOAA, 1992), and no water depth measurements were available in areas deglaciated between 1992 and 2020. This area includes the fjord immediately downslope from Landslide A and the Kite.

The subaerial lidar data were collected on June 26, 2020, by the DGGS (Daanen and others, 2021). The data have a nominal horizontal spatial resolution of $10 \mathrm{~cm}$ and a nonvegetated vertical accuracy of $7.7 \mathrm{~cm}$. They are provided in the horizontal coordinate system of North American Datum of 1983 (NAD 83; 2011), Universal Transverse Mercator (UTM) $6 \mathrm{~N}$, and North American Vertical Datum of 1988 (NAVD 88) National Geodetic Survey Geoid Model 12B (GEOID12B).

We leveraged three bathymetric datasets with differing spatial resolutions and dates (fig. 3). Higher resolution bathymetric data were collected in Barry Arm and Harriman Fjord between August 12 and 23, 2020, by NOAA (NOAA, 2020). These data have a nominal spatial resolution of 4 meters (m) and are in the horizontal coordinate system of NAD 83 (2011) UTM $6 \mathrm{~N}$ and vertical datum mean lower-low water (MLLW). We relied upon coarser resolution bathymetric data in other locations. In Passage Canal near Whittier, Alaska, NOAA has collected topobathymetric data with a nominal spatial resolution of $10 \mathrm{~m}$ (NOAA, 2009b). Simulation in the rest of Prince William Sound relied upon a topobathymetric data with a nominal 50-m resolution (NOAA, 2009a). These two NOAA datasets use a vertical datum of mean higher high water (MHHW). 


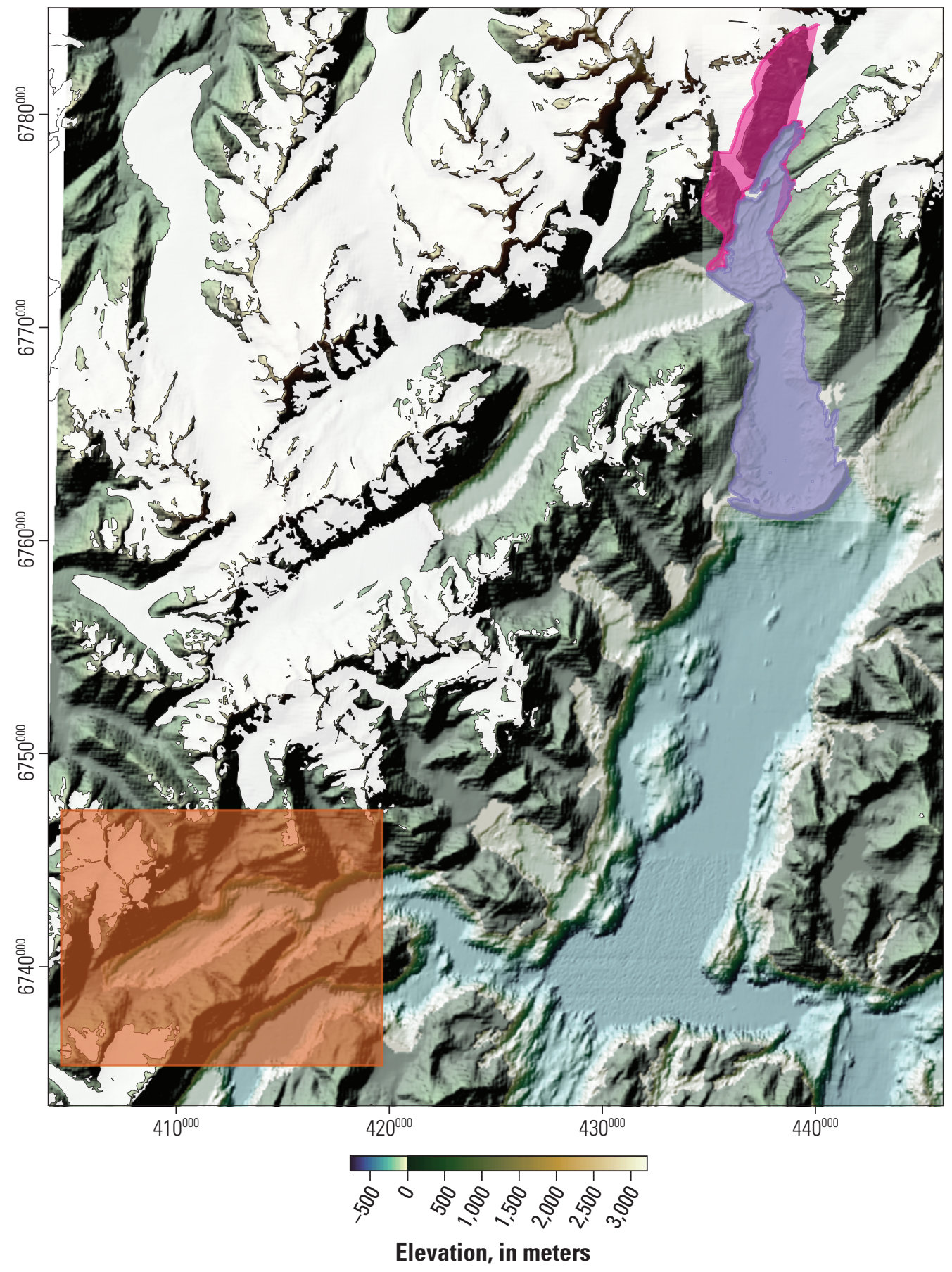

Figure 3. Extent of topographic and bathymetric data sources. The entire extent of this figure (and fig. 1A) is covered by 50-meter topobathymetry for Prince William Sound (National Oceanic and Atmospheric Administration [NOAA], 2009a), and the orange extent here is covered by 10-meter topobathymetry (NOAA, 2009b). Purple indicates the extent of new bathymetric data and magenta indicates the extent of the new subaerial light detection and ranging (lidar) data, and, both from 2020 (respectively, NOAA, 2020; Daanen and others, 2021). Easting and northing coordinates are in North American Datum of 1983 (NAD 83) Universal Transverse Mercator (UTM) Zone $6 \mathrm{~N}$ (European Petroleum Survey Group [EPSG] code 26906). Hillshade vertical exaggeration (VE) equal to 3. 
We projected all data into the horizontal projected coordinate system of NAD 83 (2011) UTM $6 \mathrm{~N}$, in which the Barry Arm topographic data and bathymetric data were collected. These new datasets were translated from their original vertical coordinate systems to MHHW based on the offset between MHHW, MLLW, and NAVD 88 at Whittier, Alaska (NOAA station 9454949). At this station, MLLW is $3.715 \mathrm{~m}$ below MHHW, and NAVD 88 is $3.395 \mathrm{~m}$ below MHHW. We integrated the new datasets at a spatial resolution of $5 \mathrm{~m}$ for use as simulation input files.

\section{Landslide Source Characteristics and Scenario Design}

Which portions of Landslide A, Landslide B, and the Kite will further destabilize, resulting in rapid landslide motion, is considerably uncertain. Additional unknowns include

(1) whether these landslides may move together or separately,

(2) what the landslide volumes are, and (3) how mobile each landslide is. To account for this uncertainty, we considered multiple scenarios (table 1) created by combining two landslide volumes with two landslide mobilities. In this preliminary report, we considered only the case in which all three landslides fail concurrently. We used this scenario because we expect this choice to generate the largest subsequent wave. However, it may be the case that different scenarios than what was considered here would produce a larger wave (for example, different landslide geometries, material properties, landslide motion sequences, and (or) destabilization of areas not yet recognized as being susceptible to failure). Further, identifying the relative or absolute likelihood for rapid motion of each landslide or kinematic element is beyond the scope of this report; therefore, we consider the scenario in which all rapidly move together. We additionally note that our scenario design is meant to represent synchronous rapid motion of the landslides from intrinsic factors, rather than motion that might occur associated with an earthquake or other exogenous event. Strong ground motion might result in additional locations of ground failure and the generation of tsunamis by multiple landslides and (or) coseismic seafloor motion.

\section{Landslide Failure Surface}

The choice to consider the rapid motion of all three landslides enforces the planimetric extent of the landslide region, but there is additional uncertainty in the spatially variable depth to the landslide failure surface and thus the landslide volume. The failure surface is the surface between destabilized material (above), which may rapidly move, and stable material (below). In this preliminary report, we did not undertake extensive slope stability analysis (for example, Reid and others, 2000, 2015). Because no information was available regarding the depth of the failure surfaces or their geometry, we approximated the failure surface with a series of logarithmic spirals oriented in the downslope direction (fig. 4). Such a curve is a common choice for a curved failure surface in geotechnical engineering (for example, Chen, 1975; Das, 2020 ) and represents an upper bound for landslide size. In polar coordinates $(r, \theta)$, a log spiral is defined as

$$
r=r_{0} e^{\theta \tan \phi}
$$

where

$r_{0}$ and $\phi$ are positive constants.

Table 1. Summary of four considered scenarios including key simulation input parameter values.

$\left[\mathrm{m}^{2}\right.$, square meter]

\begin{tabular}{|c|c|c|c|c|c|c|}
\hline \multirow{2}{*}{\multicolumn{3}{|c|}{ Simulation input parameters }} & \multicolumn{4}{|c|}{ Scenario name and description } \\
\hline & & & NC-290 & C-290 & NC-689 & C-689 \\
\hline Symbol & Units & Description & $\begin{array}{l}\text { Smaller, noncon- } \\
\text { tractive, less mobile }\end{array}$ & $\begin{array}{l}\text { Smaller, contrac- } \\
\text { tive, more mobile }\end{array}$ & $\begin{array}{l}\text { Larger, noncontrac- } \\
\text { tive, less mobile }\end{array}$ & $\begin{array}{l}\text { Larger, contrac- } \\
\text { tive, more mobile }\end{array}$ \\
\hline$\alpha$ & degrees & Headscarp angle & 45 & 45 & 60 & 60 \\
\hline$C$ & unitless & $\begin{array}{l}\text { Logarithmic spiral coefficient } \\
\text { (defined in equation 2) }\end{array}$ & 1.0 & 1.0 & 0.5 & 0.5 \\
\hline$m_{0}$ & unitless & Initial solid volume fraction & 0.64 & 0.62 & 0.64 & 0.62 \\
\hline$m_{\text {crit }}$ & unitless & $\begin{array}{l}\text { Critical state solid volume } \\
\text { fraction }\end{array}$ & 0.64 & 0.64 & 0.64 & 0.64 \\
\hline$\varphi$ & degrees & Basal friction angle & 36 & 36 & 36 & 36 \\
\hline$\varphi_{\Delta}$ & degrees & Basal friction angle offset & 10 & 0 & 10 & 0 \\
\hline$k_{0}$ & $\mathrm{~m}^{2}$ & Hydraulic permeability & $10^{-10}$ & $10^{-10}$ & $10^{-10}$ & $10^{-10}$ \\
\hline
\end{tabular}


The elevation and location of the headscarp and toescarp imply an average ground surface slope of $\Phi$, and equation 1 requires that in the following relation among $\Phi$, the headscarp angle $\alpha$, and the toescarp angle $\beta$ (all shown in fig. $4 D$ ) the value $C$ be equal to 1 .

$$
C=\frac{\phi-\alpha}{-(\phi-\beta)}
$$

This constraint derives from the log spiral having a constant derivative in polar coordinates. However, logarithmic spirals with very similar headscarp and toescarp angles, which result in a deeper logarithmic spiral and a larger landslide volume, can be constructed when this ratio (and its inverse) are both greater than about 0.5 .

We constructed the failure surface for each of the three landslides by calculating a logarithmic spiral at each of a series of downslope-oriented transects spaced $50 \mathrm{~m}$ apart (example transects shown by dotted lines in fig. 4C). For each transect, we specified the location of the headscarp and toescarp, the headscarp angle, and the ratio $C$ in equation 2. Depending on the location of the toescarp relative to the shoreline, it may be located underwater. We then calculated the value of $\beta$ implied by the other variables. A larger landslide volume can be created by a larger magnitude for $\alpha$ (more vertical) and (or) a smaller value of $C$. In between each transect, we interpolated the landslide depth to construct a spatially continuous landslide failure surface that intersects the topographic surface at the edge of each landslide. The volume contained between the failure surface and the topographic surface is the landslide volume.

Analysis of the recent lidar data (Daanen and others, 2021) constrained the headscarp angles to between 45 degrees $\left({ }^{\circ}\right)$ and $60^{\circ}$. We constructed two landslide volumes by using different values for the headscarp angle. The smaller landslide volume was constructed using a headscarp angle of $45^{\circ}$ and $C=1$ and the larger landslide volume with a headscarp angle of $60^{\circ}$ and $C=0.5$. We ensured that the failure surface was always monotonically increasing in altitude from toescarp to headscarp (that is, $\beta<0^{\circ}$ ). These choices yielded failure surfaces for all three landslide extents and a combined landslide volume of $290 \times$ $10^{6}$ and $689 \times 10^{6}$ cubic meters $\left(\mathrm{m}^{3}\right)$ for the smaller and larger options, respectively (fig. 4A, $B$ ). This combined landslide volume reflects the combination of the three landslides. The volume is partitioned between these landslides in the smaller (larger) scenarios as follows: the Kite contains $10(48) \times 10^{6} \mathrm{~m}^{3}$, Landslide A contains $214(532) \times 10^{6} \mathrm{~m}^{3}$, and Landslide B contains $66(109) \times 10^{6} \mathrm{~m}^{3}$. These volumes are comparable to the prior estimates presented in Dai and others (2020). They report an estimate for the volume of Landslide A of $455 \times 10^{6} \mathrm{~m}^{3}$, 15 percent smaller than our upper bound estimate for that landslide. We will refer to the smaller landslide volume case with the designator 290 and the larger case with 689, reflecting the landslide volumes in millions of cubic meters.

The smaller landslide volume is comparable to the volume of water immediately adjacent to the unstable region $\left(200 \times 10^{6} \mathrm{~m}^{3}\right)$. Near the toe of Landslide A and the Kite is a narrow region with probable submarine landslide material. That is, the basal-slip surface of Landslide A may intersect the land surface below water in this location. In this region, the model is initialized with solid volume fraction lower than that of the landslide, reflecting the weighted average of pure water thickness and landslide thickness implied by the bathymetric and failure surface depths. The geometry of the landslides and the geometry of the adjacent body of water are comparable (table 2), and therefore, the use of the shallow water assumptions for this application is valid.

We considered two landslide volumes for multiple reasons. First, these two volumes reflect uncertainty in the depth and geometry of the failure surfaces. Second, comparing multiple volumes supports assessing the sensitivity of the tsunami height to the landslide volume. Finally, using two landslide volumes and mobilities (described further in the "Landslide Mobility" section) permits assessing the interaction between landslide volume and material properties. Because we consider only the case in which landslide material rapidly moves from over the entire landslide extent, none of our scenarios should be considered as the smallest plausible event. Additional information may provide new constraints on the geometry of known landslides or identify additional landslides, so our largest scenario may not represent the largest possible event. However, our largest scenario does represent the largest plausible landslide volume given information that we currently have available.

Figure 4 (facing page). Landslide depth to failure surface for $A$, the smaller landslide volume and $B$, the larger landslide volume. The failure surface was constructed by fitting logarithmic spirals to a series of transects parallel to the downslope direction in the landslide. Black outlines in $A$ and $B$ demarcate the extent of Landslide $A$, Landslide $B$, and the Kite, each an independent landslide. Example transect locations are shown in $C$ as dashed lines, here spaced 400 meters apart. The yellow polygon in $C$ represents the main body of Landslide $A$, and the solid black line goes through the centroid (white dot) at an orientation perpendicular to the downslope direction. The transect shown in $D$ is from the thick dashed line in $A-C$. It extends from the headscarp location (red dot) to the toescarp location (green dot). The logarithmic-spiral fitting can support relatively larger or smaller landslide depths by modifying the headscarp $(\alpha)$ and toescarp $(\beta)$ angles to create either a shallower failure depth (smaller landslide) or deeper failure depth (larger landslide) as shown by the purple and brown lines in $D . \Phi$ is the average slope angle. The base map in $A$ and $B$ reflects a hillshade (no vertical exaggeration) based on the bathymetric and topographic data in 2020 (respectively, National Oceanic and Atmospheric Administration [NOAA], 2020; Daanen and others, 2021). Where recent data are not available (upper left-hand corner of $A$ and $B$ ) the 50-meter dataset is used (NOAA, 2009a). Easting and northing coordinates are in North American Datum of 1983 (NAD 83) Universal Transverse Mercator (UTM) Zone 6 N (European Petroleum Survey Group [EPSG] code 26906). Hillshade vertical exaggeration (VE) equal to 1. 

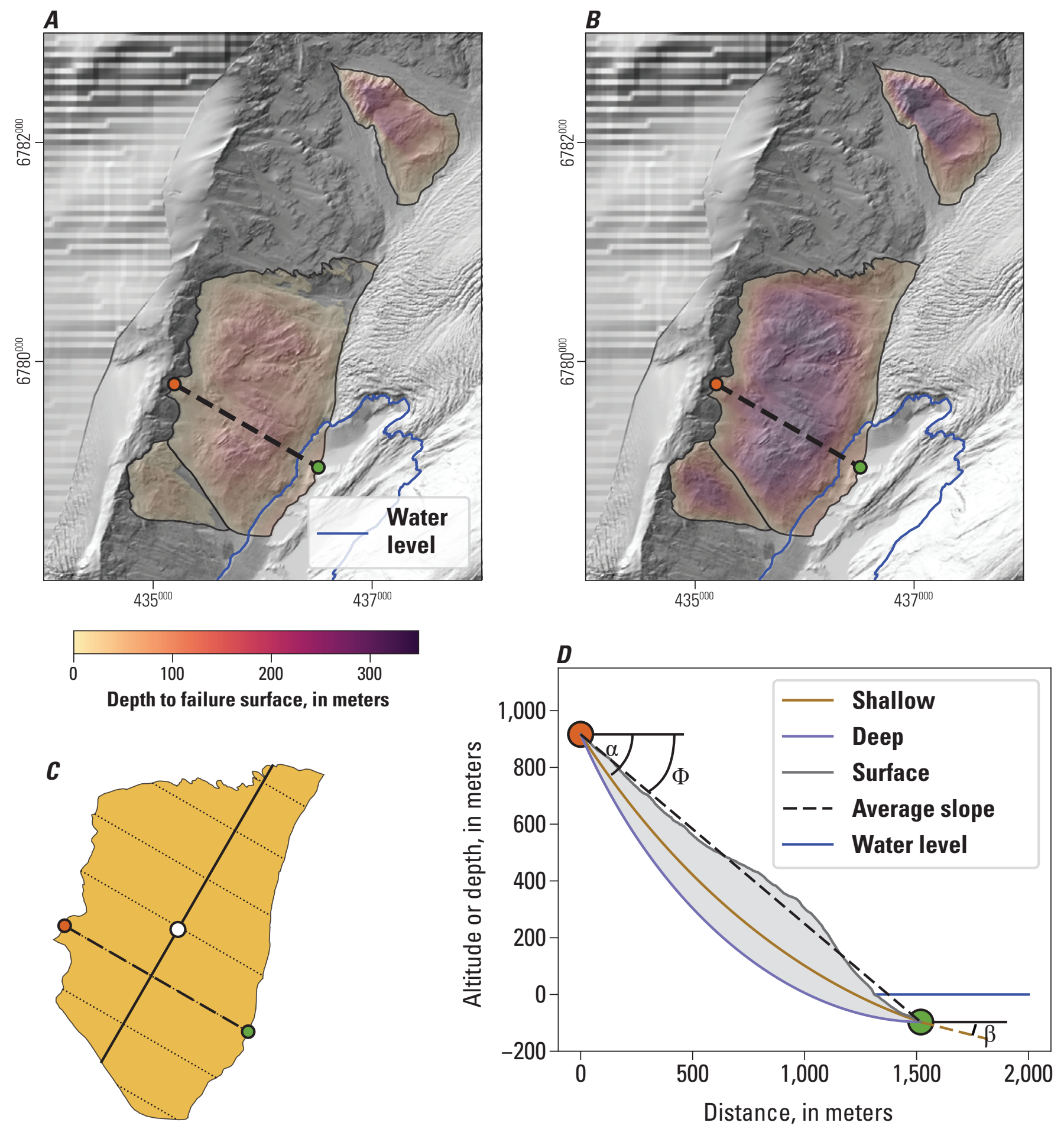
Table 2. Summary of depth and volume of the two landslide geometries and adjacent waterbody.

[m, meter; $\mathrm{m}^{3}$, cubic meter]

\begin{tabular}{lcccc}
\multicolumn{1}{c}{ Area } & Mean depth, $\mathbf{m}$ & Median depth, $\mathbf{m}$ & Maximum depth, m & Total volume, $\mathbf{m}^{\mathbf{3}}$ \\
\hline Adjacent water & 71 & 70 & 136 & $200 \times 10^{6}$ \\
Larger (689) scenario & 169 & 164 & 349 & $689 \times 10^{6}$ \\
Smaller (290) scenario & 74 & 67 & 236 & $290 \times 10^{6}$ \\
\hline
\end{tabular}

\section{Landslide Mobility}

The final element of uncertainty we considered in scenario design was the mobility of the landslides. The material properties (for example, solid volume fraction and shear strength) of the landslides are not known; therefore, we considered multiple alternatives. Because little is known about the material properties of the landslide material, we lack the necessary information to determine the relative or absolute probabilities of these alternative mobilities.

As discussed earlier, an important control on landslide material mobility in D-Claw is whether the material is contractive or noncontractive. The initial motion of contractive material results in increased pore fluid pressures, which then manifest in more mobile, fluid behavior, even under high solid-volume fractions. In contrast, the initial motion of noncontractive material does not produce these high pore fluid pressures, resulting in a less mobile landslide. How the landslide behaves after it begins to move may influence momentum transfer between the landslides and the ocean water - thus influencing the form of the initial and propagating waves. To account for this uncertainty, we consider two mobility scenarios, one with more mobile, contractive landslide material and one with noncontractive, less mobile landslide material. A more or less mobile landslide might generate a larger tsunami for the following reasons: the more mobile landslide might displace water more quickly, whereas the less mobile landslide might fail more coherently, resulting in a more piston-like impact on the water. We considered both because before we undertook this study, we did not know which scenario would produce the largest wave.

Our more mobile, contractive scenarios used the same model input parameters as implemented by George and others (2017) for the Tyndall Glacier landslide as well as by Iverson and others (2015) for the Oso, Washington, landslide. The Oso landslide had an exceptionally high mobility and long runout distance (Iverson and others, 2015). This parameter set reflects the case in which the Barry Arm landslides are highly mobile. Specifically, the initial value for the solid volume fraction $m_{0}$ is set at 0.62 ; the initial value for the critical state solid volume fraction, $m_{\text {crit }}$, is set at 0.64 ; and the initial value for material hydraulic permeability $k_{0}$ is set at $10^{-10}$ square meters $\left(\mathrm{m}^{2}\right.$; table 2$)$. A negative value of $m_{0}-m_{\text {crit }}$ implies that the initial behavior of the material will be contractive (as opposed to noncontractive or dilative), and the material will be highly mobile (Iverson and George, 2014, 2016; Iverson and others, 2015). We call this parameter set the contractive set and give it a designation C. This set does not use the frictional hysteresis model of Rocha and others (2019) and sets $\varphi=36^{\circ}$ and $\varphi_{\Delta}=0^{\circ}$. A second parameter set reflects noncontractive behavior and is designated NC. Relative to the contractive case, the noncontractive case varies in only its values for $m_{0}=0.64$ and $\varphi_{\Delta}=10^{\circ}$.

For all scenarios, simulation of the ocean water requires a Manning's n value and specification of a maximum depth for bottom friction. We use a Manning's $n$ value of 0.033 seconds per inverse cube root meter $\left(\mathrm{m}^{-1 / 3} \mathrm{~s}\right)$ and a bottom friction depth of $2000 \mathrm{~m}$. The Manning's $\mathrm{n}$ value is similar to that used by George and others (2017; they used $\left.0.025 \mathrm{~m}^{-1 / 3} \mathrm{~s}\right)$ and is within the range of reasonable values (for example, see Sraj and others, 2014).

\section{Considered Scenarios}

The combination of our two options for landslide volume and two options for landslide mobility yields four scenarios which we name C-290, NC-290, C-689, and NC-689. Key parameter values for each are listed in table 1 . The scenario names reflect the combination of landslide mobility $(\mathrm{C}$, contractive; NC, noncontractive) and landslide size (290 or $689 \times 10^{6} \mathrm{~m}^{3}$ ). Thus, scenario C-290 refers to the contractive, more mobile, smaller landslide with a total landslide volume of $290 \times 10^{6} \mathrm{~m}^{3}$.

\section{Model Implementation}

Simulations were initialized with water (pure fluid) in the ocean and the ocean surface at rest (recall that we use the MHHW vertical datum as our reference height) and a granular-fluid mixture with no velocity in each of the three landslide source regions. Pore pressure was initialized to hydrostatic pressure. D-Claw supports adaptive mesh refinement, and we used a computational grid cell size of $50 \mathrm{~m}$ around the landslide and along the wave propagation path. Preliminary simulations tested smaller grid cell sizes $(5 \mathrm{~m})$ and yielded similar results. In the portions of the domain where no wave propagated, the cell size was permitted to remain at a coarse resolution of $1,000 \mathrm{~m}$.

D-Claw uses adaptive computational time steps set based on a target and maximum Courant-Friedrichs-Lewy stability criteria. We set the target to 0.25 and the maximum to 0.5 . 
Model output was written at regular intervals of 15 seconds, less frequently than the computational time steps used. We placed eight hypothetical gages in the simulation domain. These gages do not exist in Prince William Sound but represent points in the simulation domain where results were extracted for time series analysis. Easting, northing, latitude, and longitude coordinates for each gage are provided in table 3 .

It takes approximately 20 minutes ( $\mathrm{min}$ ) of simulated time for the wave to reach Whittier, Alaska, and 90 min to reach both Valdez and Cordova, Alaska. Simulations commence and in all scenarios the landslide material immediately moves downslope into the fjord water. Simulations were run for 120 min of simulated time. Computation was conducted using the U.S. Geological Survey Denali supercomputer (USGS Advanced Research Computing, 2021).

The scenarios were represented in D-Claw by specifying scalar parameter values (table 1), spatially variable surface topography, the spatially variable basal surface, and the thickness of mobile material (initial landslide thickness and water depths). Under the landslide source, the basal surface is the failure surface and elsewhere it is the seafloor or topographic surface. This potentially mobile layer is composed of either landslide material in the landslide source zone or water in the ocean. This was implemented by specifying a spatially variable solid volume fraction reflecting water (pure fluid) in the ocean and initial solid volume fraction $m_{0}$ in the landslide source. D-Claw can simulate entrainment of material from the basal surface; however, we have no information to constrain whether and how much entrainment might occur, and accordingly, we specified the simulations such that mass does not exchange between the mobile layer of water and landslide material and the basal surface. In the following text we will refer to the surface altitude of the mobile layer-which may vary in its solid volume fraction - as the "wave height."

\section{Results}

We considered four landslide scenarios, each resulting in tsunami generation. After the simulations commence at time zero, the landslide material immediately moves into the fjord water with most landslide material entering the water within 30 seconds of simulated time. Maps depict the area inundated by the landslides in each scenario for the first $4 \mathrm{~min}$ of simulated time (fig. 5).

The landslide motion generates a tsunami by displacing fjord water and exchanging momentum with it. The largest wave was generated by the larger, contractive, more mobile scenario C-689. As shown in figure 5, this scenario inundates a larger portion of the fjord than the other scenarios and does so more quickly. In describing the results, we adopt the terminology introduced by Walder and others (2003) to describe spatial domains. The splash zone is near the landslide source and runout areas and is characterized by complex hydrodynamics: in the near field, the tsunami organizes into a coherent wave and in the far field, the tsunami dispersive effects become important. Scenario C-689 generates waves of almost $200 \mathrm{~m}$ in height in the splash zone. These waves reach Whittier, Alaska, in just over $20 \mathrm{~min}$ (in the remainder of this report, times refer to time since simulation commenced). Peak wave height in Whittier, Alaska, occurs at $26 \mathrm{~min}$. At the transition between the splash zone and the near field, located just north of the junction of Harriman Fjord and Barry Arm, scenario C-689 generates a wave of $25 \mathrm{~m}$. This wave attenuates to just over $2 \mathrm{~m}$ at gage 8 , located $500 \mathrm{~m}$ offshore Whittier, Alaska, in Passage Fjord. All other scenarios result in a wave of just under $1 \mathrm{~m}$ at gage 8 .

In this preliminary report, we do not perform an inundation analysis at Whittier, Alaska, or any other Prince William Sound community. We present cross sections through time

Table 3. Hypothetical gage locations shown in figure 2. Easting and northing coordinates are in North American Datum of 1983 (NAD 83) Universal Transverse Mercator (UTM) Zone 6 N (European Petroleum Survey Group [EPSG] 26906).

[m, meter; NA, not applicable]

\begin{tabular}{ccccll}
\hline Gage number & Easting & Northing & Latitude & Longitude & Description \\
\hline 1 & 437170 & 6774969 & 61.1043 & -148.1655 & Base of landslide in Barry Arm \\
2 & 436983 & 6772579 & 61.0828 & -148.1682 & Junction of Barry Arm and Harriman Fjord \\
3 & 437766 & 6771072 & 61.0694 & -148.1532 & Middle of southern Barry Arm \\
4 & 438185 & 6767334 & 61.0359 & -148.1442 & Junction of southern Barry Arm and Port Wells \\
5 & 439006 & 6759012 & 60.9613 & -148.1263 & Northern Port Wells \\
6 & 431189 & 6740360 & 60.7926 & -148.2640 & Southern Port Wells \\
7 & 422674 & 6741853 & 60.8045 & -148.4210 & Eastern Passage Canal \\
8 & 408443 & 6739767 & 60.7827 & -148.6814 & Passage Canal 500 m offshore Whittier, Alaska \\
NA & 438311 & 6778944 & 61.1402 & -148.1456 & Waterline below Landslide A, white star in figure 2B \\
\hline
\end{tabular}


of the largest generated wave in the area near the landslide source, time-wave height curves at select points for all scenarios, and maximum wave height synthesis for the largest generated wave. After presenting the results, we contrasted the scenarios and compared our results with prior simulations for this area.

\section{Tsunami Generated by Scenario C-689}

The largest wave heights were generated by the larger, contractive, more mobile scenario C-689 (figs. 6-8). After the simulation commences, the landslide enters the northernmost portion of Barry Arm fjord (north of the junction of Barry Arm and Harriman Fjord). This generated runup on the opposing fjord wall in excess of $500 \mathrm{~m}$ (fig. $5 \mathrm{~A}$ ), which is comparable to the largest historical runup which was observed at Lituya Bay in 1958 (524 m; National Geophysical Data Center/World Data Service, 2020) and larger than the 300 m runup reported by Dai and others (2020).

In scenario C-689, the motion of the three landslides into the water displaced all the water in the splash zone, the northernmost portion of Barry Arm adjacent to the terminus of Barry Glacier. The combination of the landslide material and displaced water generated a wave comparable in height to the water depth (maximum water depth of $136 \mathrm{~m}$, table 2). The wave then propagated into deeper water over complex bathymetry containing many shallow regions. These shallow regions are likely submarine glacial erosional features or deposits representing glacial scour into bedrock and (or) terminal moraine deposits of previous extents of Barry Glacier. We refer to these submarine features by the letters identified in figure 6 (I, II, III, and IV). Our simulations assume that the seafloor over the entire domain does not change, that is, there is no entrainment or landslide growth from this surface. We had little information to constrain the material properties of these submarine features, and if any of these features were to erode or fail in response to an overriding landslide or propagating wave, this would likely change the results. Such a change could result in either a larger or smaller wave.

When the simulated wave propagated over these features, it interacted with them, primarily resulting in a decrease in wave height. This is highlighted in figure 6 , where the maximum wave height at any point in the simulated time is shown. Glacial retreat since 2006 has exposed features I and II (Dai and others, 2020). Feature III was identified by Johnson (1916) as the 1899 extent of Barry and Coxe Glaciers. After the wave in scenario C-689 interacted with features I and II, its maximum height decreased from over $200 \mathrm{~m}$ to under $100 \mathrm{~m}$. When the wave reaches feature III, it is around $25 \mathrm{~m}$, and after passing over feature III, the maximum wave height decreases further. Finally, when the wave passed over feature IV, its maximum wave height reduced below $5 \mathrm{~m}$.

\section{Time-Wave Height Histories for All Scenarios}

The time series of wave heights for all four scenarios at the eight hypothetical gage points are shown in figures 7 and 8 , the latter of which shows only the time interval ranging from $1 \mathrm{~min}$ before to $20 \mathrm{~min}$ after the arrival of the wave. The larger, contractive, more mobile scenario C-689 is much larger than the other three scenarios, which produce similarsized waves. The accompanying U.S. Geological Survey data release includes a comma separated values (CSV) file containing the gage traces shown in figures 7 and 8 (Barnhart and others, 2021).

The wave generated by scenario C- 689 reflects the behavior described in the prior section, "Tsunami Generated by Scenario C-689." In the splash zone area immediately proximal to the landslide source area (gages 1-3), the resulting wave dynamics are complex and variable across scenarios. At some gages, time series asymptotically reached nonzero values (for example, most landslide scenarios at gage 2). These nonzero gage values indicate that the landslide source material extended at least as far as the location of that gage, creating a deposit and (or) damming water. In scenario C-689, the maximum wave height was $37 \mathrm{~m}$ near the junction of Harriman Fjord and Barry Arm (figs. 7 and 8; gage 2), decreasing to approximately $25 \mathrm{~m}$ at feature III.

Past feature III, the wave has left the landslide runout area, and the form of the propagating wave is clearer. At gage 4 , the distinction between the wave generated by the four scenarios becomes more easily interpretable. Scenario C-689 generates a much larger wave than the smaller, contractive, more mobile scenario C-290. The less mobile, noncontractive scenarios NC-290 and NC-689 show less sensitivity to the landslide volume; indeed, the smaller, noncontractive, less mobile scenario NC-290 generates a comparable but just slightly larger wave than the larger, noncontractive, less mobile scenario NC-689. At gage 4, scenario C-689 produces a wave of nearly $10 \mathrm{~m}$, over twice as large as any other scenario.

As the wave propagates over feature IV and into Port Wells (gage 5), the wave heights decreased by up to a factor of 4. The wave heights do not substantively change at the southern end of Port Wells (gage 6) or at the start of Passage Canal

Figure 5 (following page). Landslide material extent for the first 4 minutes of simulated time for $A$, scenario $C-290, B$, scenario NC-290, $C$, scenario C-689, and $D$, scenario NC-689. Landslide material identified as model grid cells where solid volume fraction exceeded 0.3 . Extent of landslide material plotted at 15 -second increments and earlier times plotted over later times. Blue line outlines the shoreline at time equal to 0 , and black line outlines the initial extent of landslide material. Easting and northing coordinates are in North American Datum of 1983 (NAD 83) Universal Transverse Mercator (UTM) Zone 6 N (European Petroleum Survey Group [EPSG] code 26906). Hillshade vertical exaggeration (VE) equal to 1. 

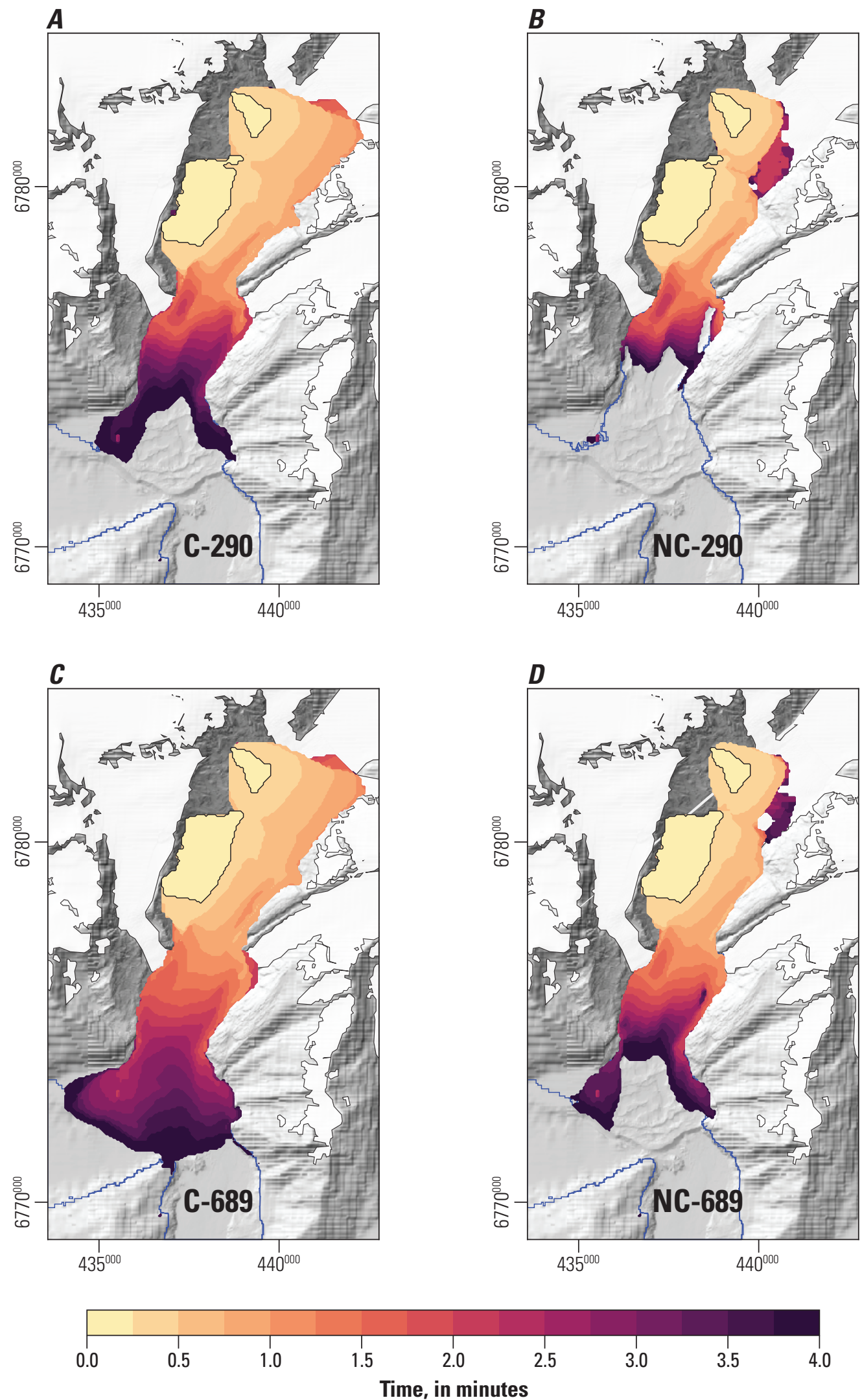

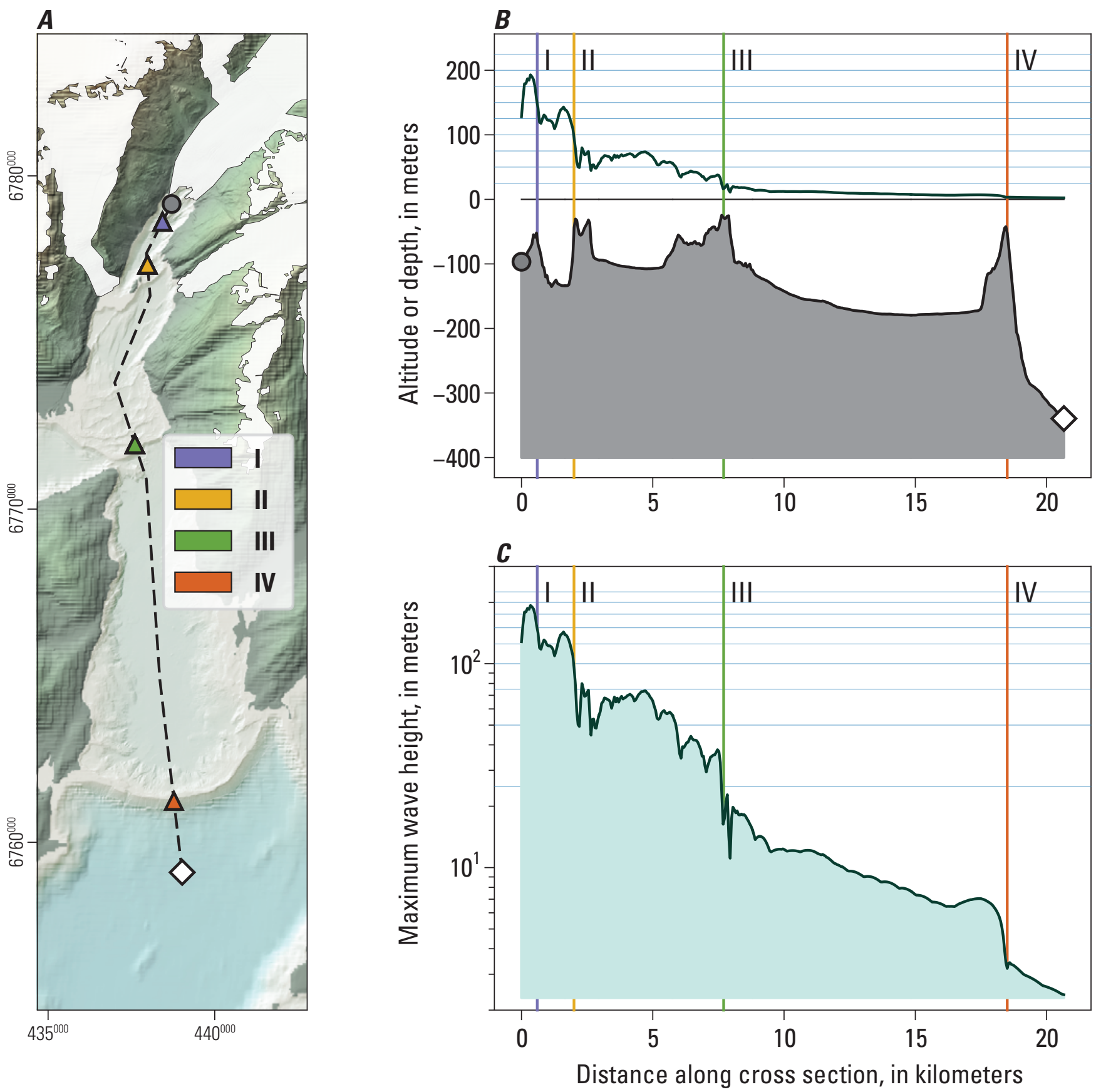

Figure 6. Barry Arm fjord from the landslide source region into Port Wells. $A$, Map indicating the location and direction of transect with the dashed line, gray dot, and white diamond. $B$, Maximum wave height in green for the larger, contractive, more mobile Scenario C-689, which produces the largest tsunami. The seafloor is indicated by the black line and dark gray region. As the wave height spans multiple orders of magnitude, the maximum wave height is also shown on a logarithmic $y$-axis scale, and values below the maximum are shaded green $(C)$. Substantial decreases in peak wave height are colocated with areas of low water depth, for example, those highlighted by vertical lines in $B$ and $C$. The locations of the vertical lines are indicated in $A$ using triangles, and the color indicates the feature identification (ID). Note that the $\mathrm{x}$-axes in $B$ and $C$ are equivalent. Easting and northing coordinates in $A$ are in North American Datum of 1983 (NAD 83) Universal Transverse Mercator (UTM) Zone 6 N (European Petroleum Survey Group [EPSG] 26906). Hillshade vertical exaggeration (VE) equal to 1. 

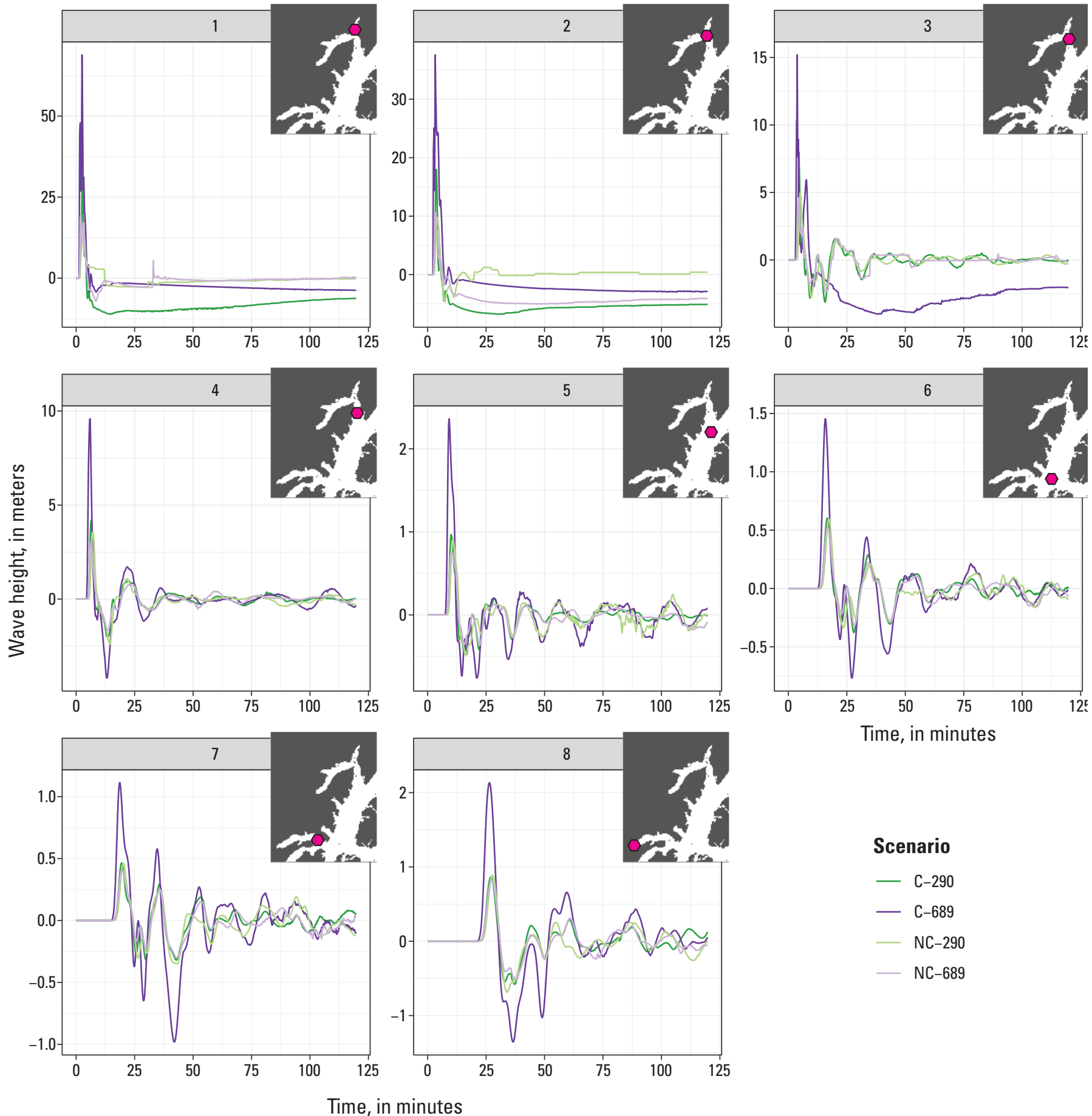

Time, in minutes

Figure 7. Wave height as a function of simulated time for each of the four considered scenarios at eight hypothetical gage locations indicated in figure 2. Extent of $x$-axis reflects the entire simulated time of 2 hours. Gage number indicated by gray bar at the top of each panel and location shown by red dot in each inset map. This inset map shows land in gray and ocean in white and represents the same region as figure $1 B$. Note that $y$-axis limits are inconsistent between panels. When the long-term asymptote of the wave height trace does not go to zero, this is an indication that landslide material has extended to the gage location. 

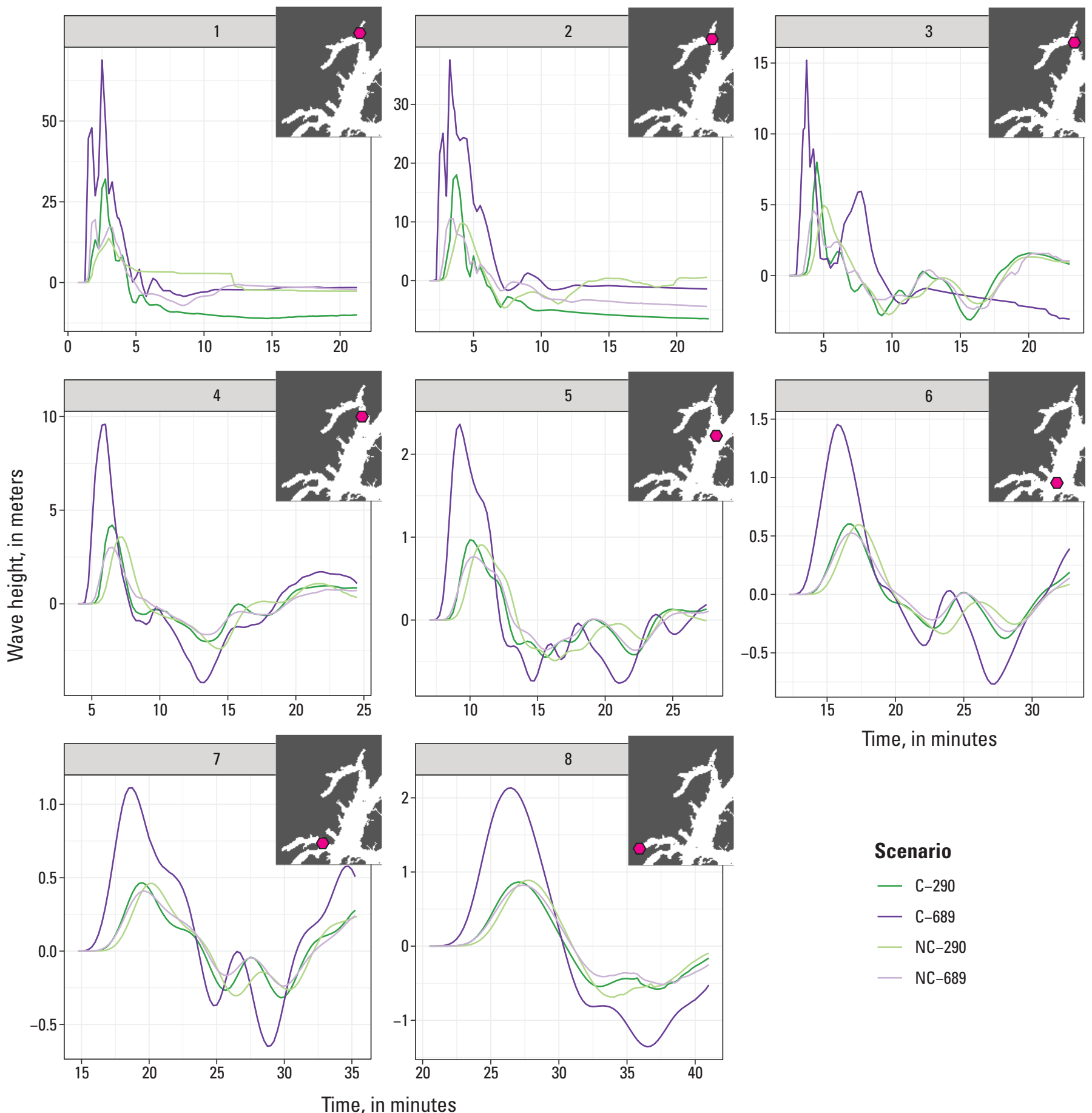

Time, in minutes

Figure 8. Wave height as a function of simulated time for each of the four considered scenarios at eight hypothetical gage locations indicated in figure $2 B$. Extent of $x$-axis reflects a shorter duration of time than figure 7 . The $x$-axis extent here zooms into the onset of the tsunami and depicts the wave height starting 1 minute before the onset of water level increase (wave arrival) in any scenario and 20 minutes after wave arrival. Gage number indicated by gray bar at the top of each panel and location shown by red dot in each inset map. This inset map shows land in gray and ocean in white and represents the same region as figure $1 B$. Note that $y$-axis limits are inconsistent between panels. 
(gage 7). After the simulated wave propagated into shallower water near Whittier, Alaska, the wave heights increased. We do not compute detailed inundation for the town of Whittier, Alaska, or other Prince William Sound communities. Gage 8 shows the water levels in Passage Canal $500 \mathrm{~m}$ offshore Whittier, Alaska: they reached just over $2 \mathrm{~m}$ in scenario C-689, which produces the largest waves. All other scenarios have peak wave heights at Whittier, Alaska, of less than $1 \mathrm{~m}$. The water level at gage 8 began to rise at $20 \mathrm{~min}$ and reached a peak height around $26 \mathrm{~min}$.

\section{Maximum Wave Height Generated by Scenario C-689}

The maximum wave height for the larger, contractive, more mobile scenario C-689 is shown in figure 9. The entirety of Prince William Sound is shown, as well as maps focused on the landslide source area, the westernmost portion of Passage Canal, and the domain between Barry Arm and Whittier, Alaska. Tsunami travel time (fig. 10) and time of maximum wave height (fig. 11) were also computed for the same extents as figure 9. The map of maximum wave height reflects the patterns of wave propagation presented in the prior two sections, "Tsunami Generated by Scenario C-689" and "TimeWave Height Histories for All Scenarios.” The accompanying U.S. Geological Survey data release for this report includes Geostationary Earth Orbit Tagged Image File Format (GeoTIFF) files containing the maximum wave height, the time of maximum height, and the tsunami travel time presented in figures 9-10 (Barnhart and others, 2021).

Wave heights exceeding half a meter in scenario C-689 were not extensive outside of the Port Wells region (fig. 11). Wave heights exceeding $20 \mathrm{~m}$ were primarily simulated in northern Barry Arm (fig. 11). Wave heights exceeding 5 m, but less than $20 \mathrm{~m}$, were simulated in southern Barry Arm, Harriman Fjord, and along the shorelines and inlets of Port Wells near the junction of Port Wells and Barry Arm (fig. 11). The maximum wave height was greatest at the heads of fjords, likely because water depths decrease in those locations and because of focusing of tsunami energy.

\section{Discussion}

The presented simulations represent four hypothetical landslide scenarios at Barry Arm and the generation and propagation of a tsunami generated by rapid landslide motion. The scenarios were computed using the D-Claw model, which is capable of simulating landslide dynamics, a propagating wave in water, and the interactions between both. Here, we discuss the implications of the variations in results across scenarios as well as compare our results to prior simulations at this site.

Our scenario design considers only the case in which all three landslides concurrently fail. We reiterate that the material properties of the landslides are unknown, the actual size of the landslides is unknown, and the relative probability of different scenarios is unknown. Thus, we vary the geometry of hypothetical landslide failure surfaces to create plausible geometries for landslide volumes, constrained by the mapped extent of the kinematic elements and headscarp angles (Coe and others, 2021; Daanen and others, 2021). Similarly, we vary the material properties to create more mobile, contractive landslides and less mobile, noncontractive landslides. The motion of all landslides together and the design of the "larger" C-689 and NC-689 scenarios are intended to reflect the largest plausible volume given current observational constraints. As additional information becomes available, this volume may be refined and changed. Taken together, these scenario design decisions are intended to create the largest plausible wave; however, we stress that other landslide geometries, landslide motion sequences, material properties, and model assumptions may produce a larger wave.

\section{Scenario Comparison}

The clearest result that comes from comparing the four scenarios is that the larger, contractive, more mobile scenario C-689 generated the largest tsunami, and all other scenarios generated a similar sized tsunami. We focus the remainder of this subsection on exploring why scenario C-689 produced a larger tsunami than the other scenarios. One approach to this would be to calculate the landslide velocity upon impact. We do not do this because our simulations did not represent the landslide as a rigid block.

In figure 5, we presented the extent of the simulation domain inundated with landslide material through time. This figure shows that scenario C-689 inundated a larger portion of the fjord and did so more quickly than the other scenarios. To further examine the differences between the scenarios, we estimated the volume of fjord water displaced through time in each of the scenarios (fig. 12). We estimated the displaced water by calculating the volume of water that was initially present in the areas where landslide material is present (defined as material with solid volume fraction greater than 0.3). Because this calculation does not consider mixing between landslide material and fjord water, it should be considered as a rough estimate. Scenario C-689 displaces the most water of all the scenarios and the rate of displacement (slope of the line) is faster than the other scenarios (fig. 12).

Next, we examined how material at the base of Landslide A behaves right at the initiation of motion. In figure 13, we plot time series of wave height, velocity, and momentum for a point at the base of Landslide A (white star in fig. 2B). This point was chosen to represent the motion of landslide material as it entered the water. Tracking the boundaries between the landslide material, the mixing region, and displaced water is beyond the scope of this contribution. The wave height time series (top panel) show that the wave height at the base of the slides is similar between the two smaller (C-290 and NC-290) and two larger (C-698 and NC-689) scenarios, but that the 

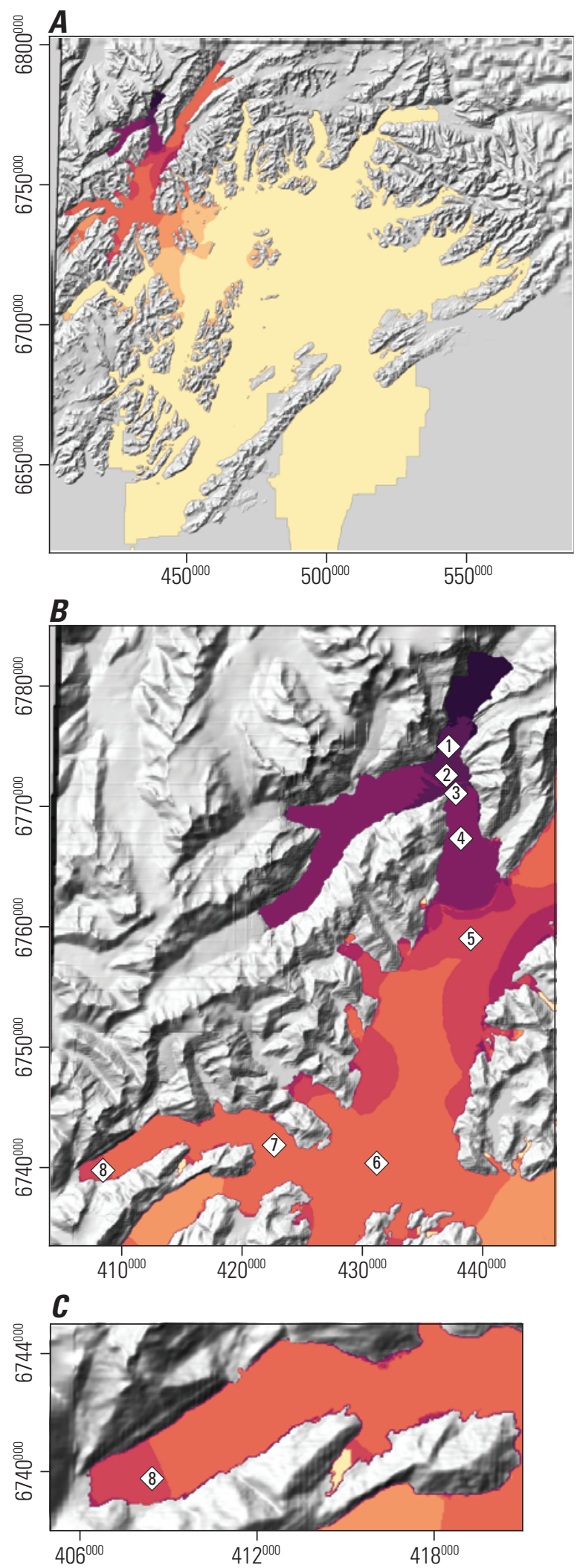

Figure 9. $A-D$, maximum wave height for the larger, contractive, more mobile scenario $C-689$, which produces the largest tsunami. Extent of panels $B-D$ shown in figure 1. Note that at grid cells which were initially dry, but inundated during the simulation, the value plotted here does not indicate inundation depth. Color scale is not uniform. Location and identification (ID) number for hypothetical gages indicated with white diamonds (coordinates provided in table 3). Easting and northing coordinates are in North American Datum of 1983 (NAD 83) Universal Transverse Mercator (UTM) Zone 6 N (European Petroleum Survey Group [EPSG] 26906). Hillshade vertical exaggeration (VE) equal to 3. 

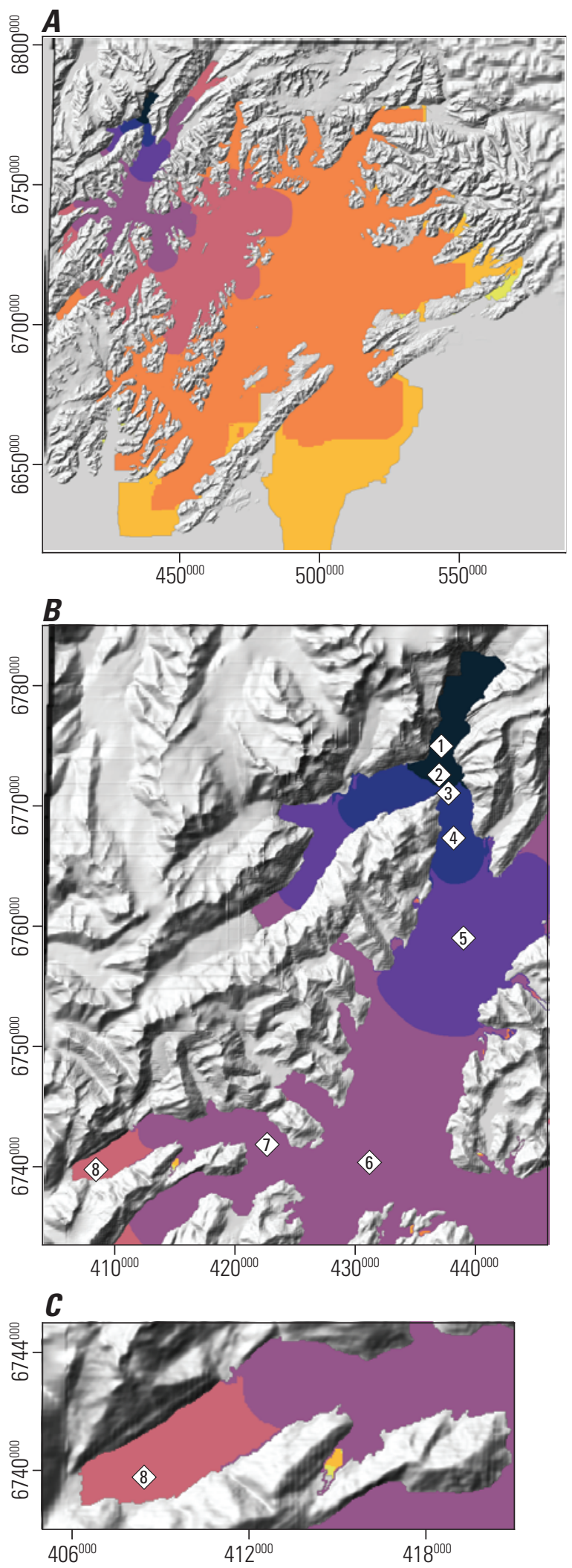

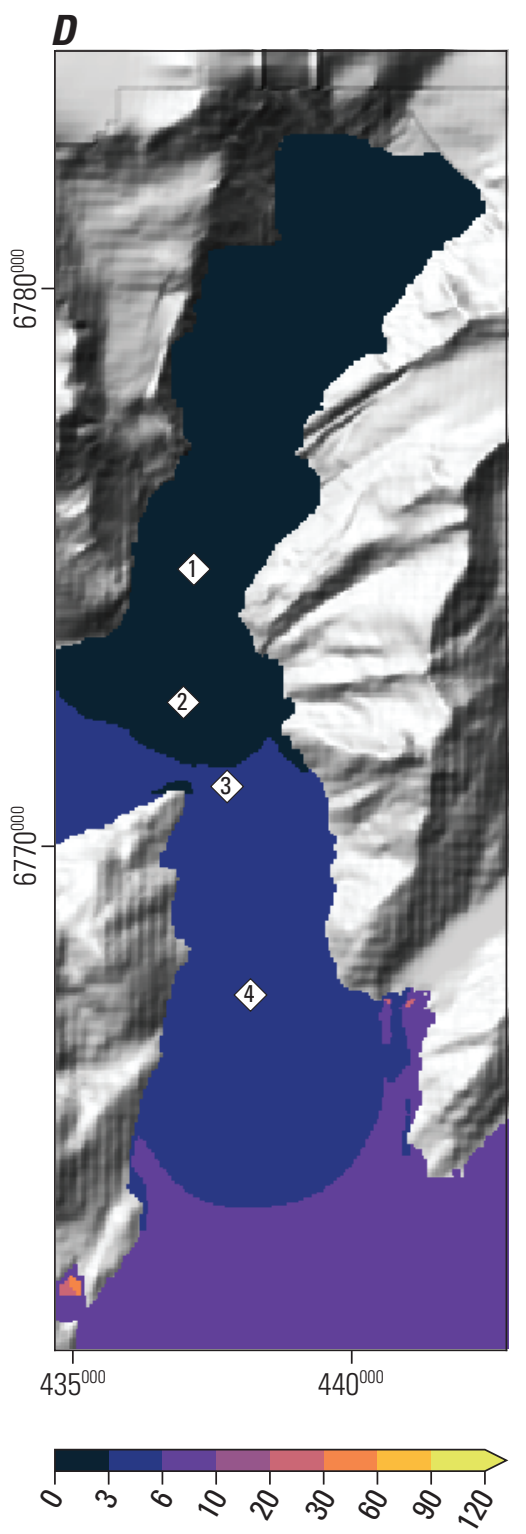

Tsunami travel time, in minutes

Figure 10. $A-D$, tsunami travel time for the larger, contractive, more mobile $C-689$ scenario which produces the largest tsunami. Extent of panels $B-D$ shown in figure 1. Travel time defined as the first output time step (output written every 15 seconds) in which water levels exceeded 1 centimeter. Time is in minutes since simulation initiated and rapid landslide motion occurred. Color scale is not uniform. Location and identification (ID) number for hypothetical gages indicated with white diamonds (coordinates provided in table 3). Easting and northing coordinates are in North American Datum of 1983 (NAD 83) Universal Transverse Mercator (UTM) Zone 6 N (European Petroleum Survey Group [EPSG] 26906). Hillshade vertical exaggeration (VE) equal to 3. 

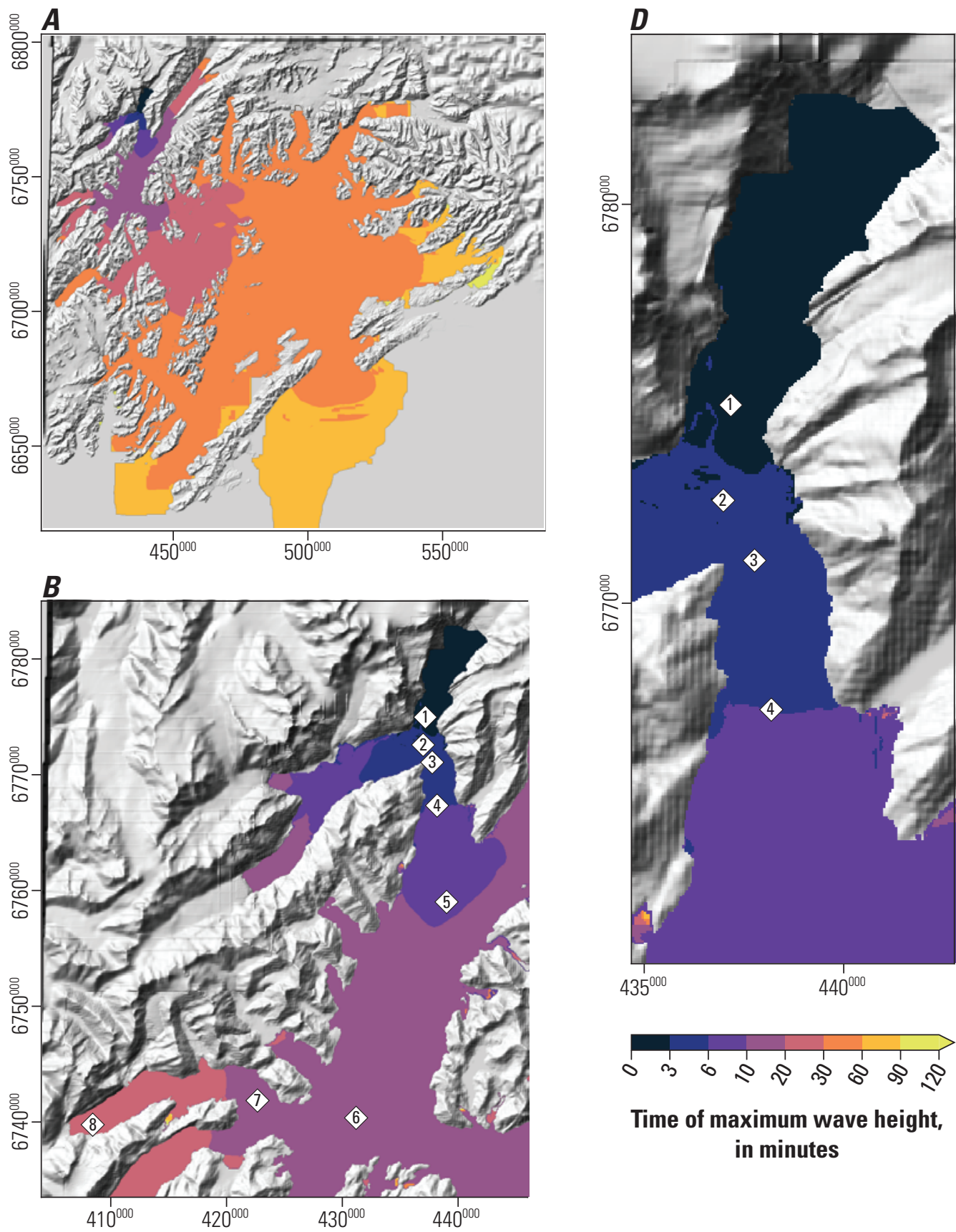

\section{Time of maximum wave height, in minutes}

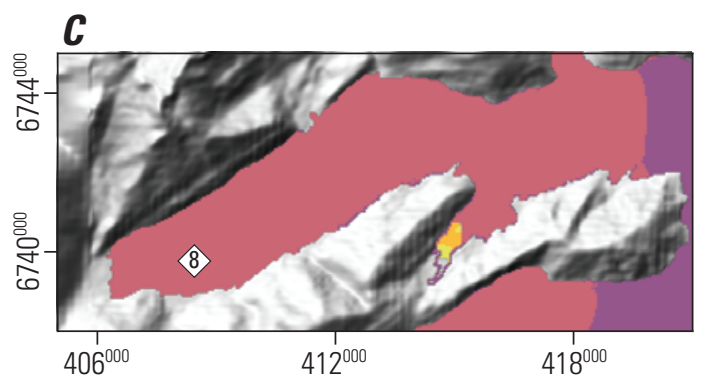

Figure 11. $A-D$, time of peak wave height for the larger, contractive, more mobile C-689 scenario which produces the largest tsunami. Extent of panels $B-D$ shown in figure 1. Time is in minutes since simulation initiated and rapid landslide motion occurred. Color scale is not uniform. Location and identification (ID) number for hypothetical gages indicated with white diamonds (coordinates provided in table 3). Easting and northing coordinates are in North American Datum of 1983 (NAD 83) Universal Transverse Mercator (UTM) Zone 6 N (European Petroleum Survey Group [EPSG] 26906). Hillshade vertical exaggeration (VE) equal to 3. 


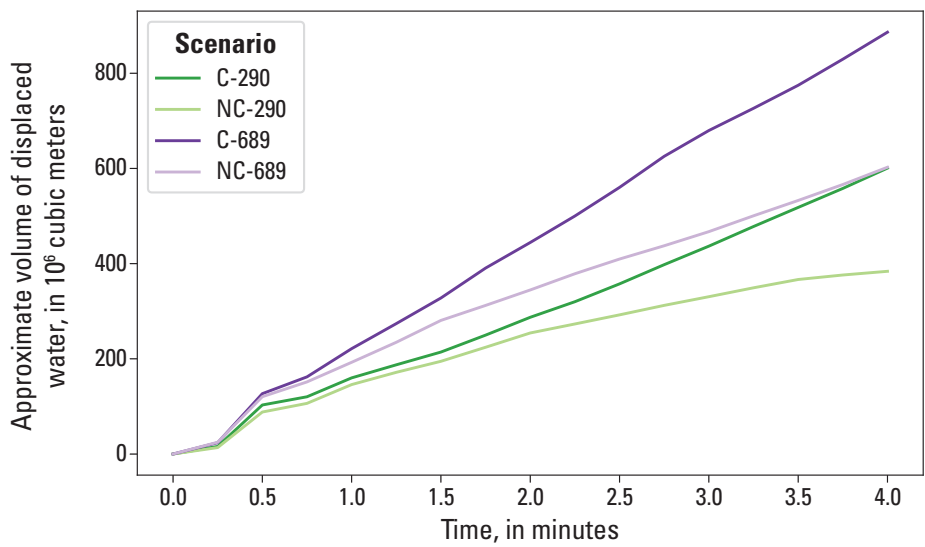

Figure 12. Approximate volume of fjord water displaced by landslide material for each of the four considered scenarios. Displaced volume estimated as the volume of initial fjord water displaced by material with solid volume fraction greater than 0.3 .

larger scenarios displace water faster (purple lines have a steeper initial slope than green lines). Because the larger scenarios represent more landslide material, larger wave heights in these scenarios than in the smaller scenarios is not surprising.

The largest velocities come from the smaller, contractive, more mobile scenario (C-290). The middle panel shows that the smaller, contractive, more mobile scenario moves more quickly than its noncontractive, less mobile counterpart. This same pattern persists for the larger scenarios in that the larger, contractive, more mobile scenario C-689 reaches larger velocities than its noncontractive counterpart. This separation in velocity between the more mobile, contractive scenarios and the less mobile, noncontractive scenarios makes sense after recalling how D-Claw conceptualizes landslide material. If material is contractive, initial motion increases pore pressures, thereby reducing intergranular friction. This reduction in intergranular friction results in a more efficient conversion of potential energy into kinetic energy.

The most substantial difference between the largest tsunami-generating scenario C-689 and the other scenarios is shown in the momentum plot (fig. 13C). The combination of landslide thickness from the large landslide volume and landslide speed from contractive, more mobile material results in substantially higher momentum values in scenario C-689. By combining the analysis of displaced volume and the analysis of behavior at the landslide source, we conclude that both mass displacement and momentum exchange are important processes for wave generation at the Barry Arm location.

A final point of scenario intercomparison is to note that the generated tsunami is more sensitive to the landslide material in the contractive, more mobile scenarios than in the noncontractive, less mobile scenarios. Indeed, the two noncontractive scenarios, which differ in landslide volume by more than a factor of 2 , generate similar tsunamis. The extent to which this finding is unique to the landslide volumes and mobilities considered here, and to the geometry of the Barry Arm landslide site, is not known. The comparison of the four scenarios points to the importance of constraining both material properties and landslide geometry to better bracket the forecast wave magnitude.

\section{Comparison with Prior Work}

In this section of the discussion, we compare our results with prior tsunami simulations conducted by Dai and others (2020). We note that these authors did their work before new bathymetric and topographic data were collected. These data, which were necessary for our direct simulations of tsunami, were not available to these authors. Given this lack of observational information, Dai and others (2020) used a first principles style approach to generate a series of hypothetical initial tsunami waveforms intended to capture the order of magnitude of tsunami crest height and length scales. They initialized their sea surface with these waveforms and simulated the propagation of the initial waveform. To most succinctly describe how they initialized their simulations we quote from the supplementary material of Dai and others (2020, p. 6): "The cross-channel profile of the initial tsunami follows a Gaussian shape, with a half width of 1 kilometer $(\mathrm{km})$. In the along-channel direction, the tsunami is described as a half-sine wave with length $2 \mathrm{~km}$ [with initial crest height of $150 \mathrm{~m}$ ], yielding a displaced volume of water equal to $1 / 3$ the volume of the landslide. The initial speed under this wave is calculated with nonlinear long wave theory with a channel-aligned direction pointing away from the landslide source." To reflect uncertainty in the size of the initial tsunami form, Dai and others (2020) considered multiple initial 

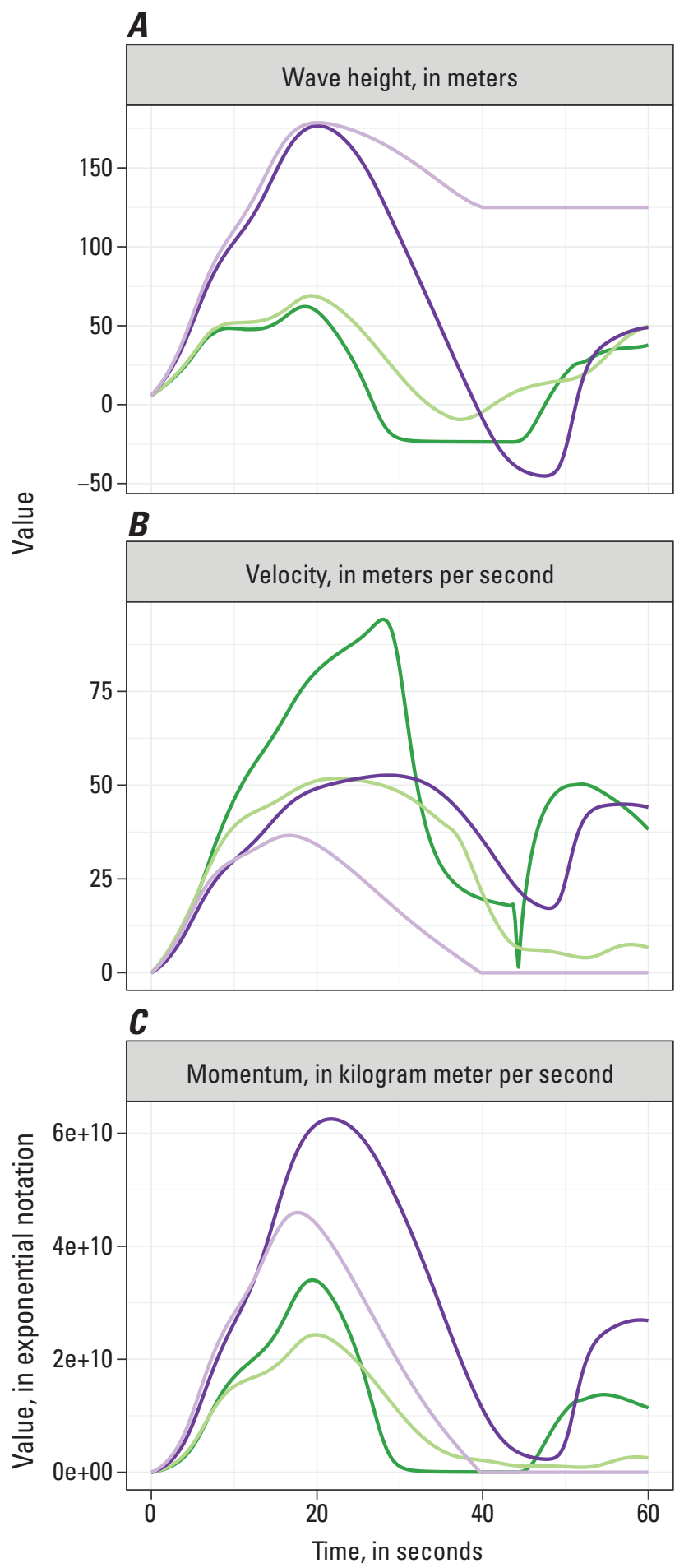

Scenario

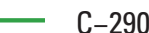

- NC-290

${ }^{-6.89}$

NC-689

Figure 13. $A$, Wave height, $B$, velocity, and $C$, momentum for the first minute of simulation taken from the location labeled by the white star in figure $2 B$ (location given in table 3 ). crest heights for the tsunami waveform: $25,75,150$, and $300 \mathrm{~m}$. For clarity, we will refer to these four scenarios as D-25, D-75, D-150, and D-300.

Making a direct comparison between the scenarios presented by Dai and others (2020) and those presented here is difficult because where in space and at what point in simulated time the waveforms should be compared is not clear. One quantity that is easier to compare is the tsunami arrival and peak wave height times. Our scenarios generated tsunami arrival times at gage 8 (500 m offshore Whittier, Alaska) of approximately $20 \mathrm{~min}$ after the initial motion of the landslides and peaks around $26 \mathrm{~min}$. Our results indicate nearly identical timing of wave arrival and wave peak times as prior simulations presented in figure S9 of Dai and others (2020).

Another variable that is possible to compare is tsunami runup. Dai and others (2020) report runup values adjacent to their initial waveform of nearly $300 \mathrm{~m}$ for scenario D- 150 . In contrast, we see runup values of between $200 \mathrm{~m}$ (scenario NC-290) to over $500 \mathrm{~m}$ (scenarios C-689 and NC-689). No scenarios impact the Barry Arm East (BAE) seismic station (located at an elevation of $578 \mathrm{~m}$, plan view location indicated by the white plus in fig. $2 B$ ).

To more fully compare our simulated tsunami with the scenarios considered by Dai and others (2020), we plotted evolution of solid volume fraction, wave height, and flow direction for scenario C-689 at $0,1,2,3$, and 4 min of simulated time (fig. 14). This figure shows that the landslide material pushes the water out of the splash zone north of Point Doran. During this time, the direction of flow in the tsunami was not always oriented down fjord to the south (for example, at $3 \mathrm{~min}$ after rapid landslide motion, the wave height is higher on the west side of the fjord than the east, and the flow is to the southwest). As the landslide material runs out, it reflects off the opposing fjord wall (for example, the northwest and southeast directed flow at $1 \mathrm{~min}$ in fig. 14). The orientation of the landslide relative to the fjord means that much of the initial landslide momentum is not oriented in the direction of coherent tsunami propagation.

By the time the wave reached feature III (fig. 6) and propagated into the southern portion of Barry Arm, its form and direction were coherent, meaning the dominant direction of flow momentum was aligned down fjord. As the tsunami propagated over feature III, its maximum wave height was approximately $25 \mathrm{~m}$ (figs. 6 and 14). Because feature III is the location where the tsunami transitioned from the splash zone to the near field, and where it began propagating as a coherent wave directed down fjord, we concluded that the maximum tsunami wave height at feature III is the most comparable value to the initial crest heights used by Dai and others (2020). This implies that our largest wave-generating scenario, C-689, is most comparable to their scenario D-25.

An additional difference between our results and those of Dai and others (2020) is the type of wave model used. While D-Claw uses the shallow water approximations, Dai and others (2020) used pCOULWAVE (Lynett, 2006), a code that implements a nonlinear, dispersive Boussinesq-type wave 
$\boldsymbol{A}$

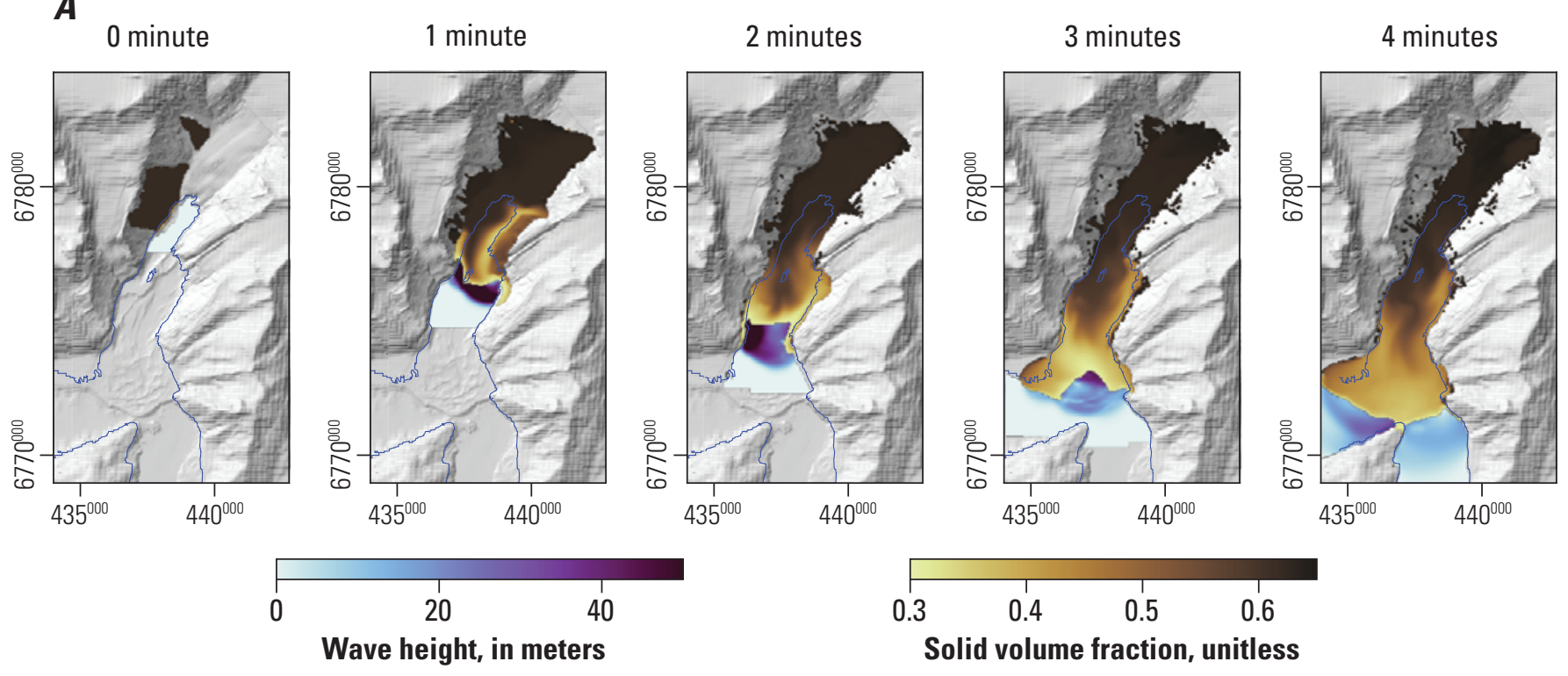

$B$
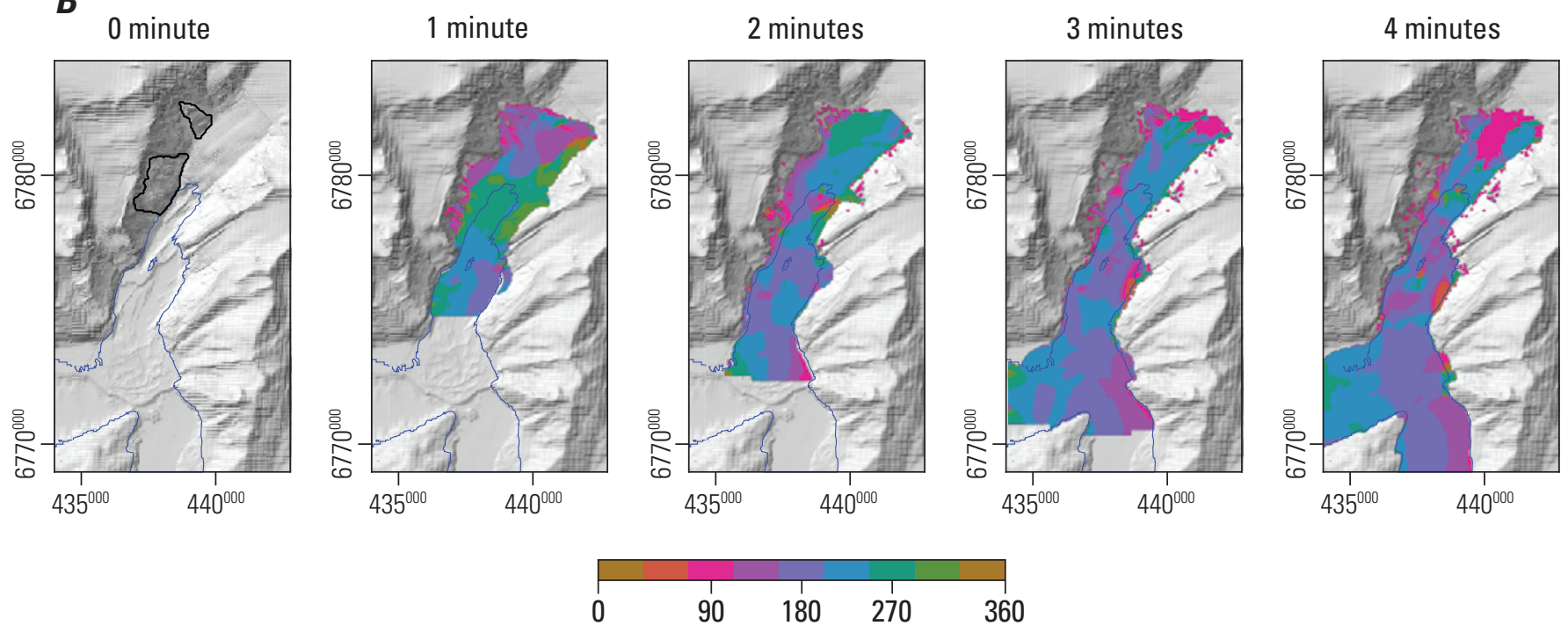

Direction, in degrees clockwise from north

Figure 14. Time evolution of the wave generated by the larger, contractive, more mobile scenario $\mathrm{C}$-689. Columns represent snapshots at $0,1,2,3$, and 4 minutes of simulated time. In the upper row $(A)$ the solid volume fraction is plotted if it exceeds 0.3 and the wave height is plotted elsewhere. The lower row $(B)$ shows the direction of motion in degrees ( 0 is north, 90 is east, 180 is south, and 270 is west). Values for wave height, solid volume fraction, or direction are only plotted when the grid refinement level is at its highest level. The blue line represents the initial shoreline. Easting and northing coordinates are in North American Datum of 1983 (NAD 83) Universal Transverse Mercator (UTM) Zone 6 N (European Petroleum Survey Group [EPSG] 26906). Hillshade vertical exaggeration (VE) equal to 1. 
model (Kirby, 2016). As discussed earlier, the Boussinesqtype model may be more appropriate for the propagation of landslide-generated waves because these waves typically have shorter wavelengths. However, comparison between the simulated wave height at Whittier, Alaska, for scenario C-689 and scenario D-25 indicates that both scenarios produce a wave of approximately $2 \mathrm{~m}$ in magnitude.

\section{Importance of Topographic and Bathymetric Data}

The focus of this preliminary report is on simulating the landslide motion and initial wave generation. We are supported in this by the recent bathymetric and topographic datasets collected in 2020 (respectively, NOAA, 2020; Daanen and others, 2021). Indeed, these bathymetric data illuminate submarine features I and II for the first time (fig. 6). Our ability to directly simulate a landslide-generated tsunami in the context of the current bathymetric data means that we do not need to assume an initial waveform. Uncertainty in the size of the wave certainly exists - and primarily derives from uncertainty in the geometry and material properties of the landslide. However, direct simulation of landslide motion would not have been possible without the bathymetry acquired in August 2020.

\section{Conclusions}

The main points of the report are as follows:

- Simulation of landslide motion and subsequent tsunami generation at Barry Arm was made possible by newly collected light detection and ranging (lidar) and bathymetric data.

- Specific treatment of landslide volume and mobility influences the tsunami height, with the largest and most mobile landslide scenario producing the largest wave, and all other scenarios producing similar but smaller waves.

- Our largest modeled wave heights result from the largest plausible failure volume and a highly mobile landslide. These wave heights are similar to the smallest wave scenario presented by Dai and others (2020), even though the landslide volume considered here is greater.

- The largest scenario results in a wave with just over $2 \mathrm{~m}$ of height 500 meters offshore Whittier, Alaska. This wave arrives in Whittier, Alaska, approximately 20 minutes ( $\mathrm{min}$ ) after initial landslide motion and peaks 26 min after initial motion. Simulated wave heights exceeding $5 \mathrm{~m}$ are common throughout Barry Arm and Harriman Fjord and peak within 10 min of initial landslide motion.
- The results presented here differ from the prior simulations presented in Dai and others (2020) because we are able to directly simulate the landslide entering the ocean. We also have current bathymetric data that were not yet available during the analysis included in their paper. We compared our results to these prior simulations by examining our simulated wave heights at the location where our simulated wave becomes coherent and directed down fjord (near Point Doran). At this location, the peak wave heights from our largest scenario are approximately 25 meters. On this basis, we conclude that our largest wave-generating scenario (C-689) is most directly comparable with the smallest scenario considered by Dai and others (2020), which used a $25-\mathrm{m}$ initial wave crest height. When we compare our simulated gage traces at Whittier, Alaska, from scenario C-689 with the $25-\mathrm{m}$ initial wave scenario (fig. S9 in Dai and others, 2020), we find both simulations yield a maximum wave height of around $2 \mathrm{~m}$ and a peak wave time of about $26 \mathrm{~min}$.

We conclude by describing the limitations of this preliminary report. Herein, we only considered four scenarios based on currently available data. Given these data, these scenarios are intended to reflect uncertainty in landslide size and mobility and to demonstrate how this uncertainty propagates into tsunami height. We consider only the case in which all three landslides fail concurrently. This scenario design was intended to constrain the largest plausible tsunami-generating landslide and help inform the tsunami warning system. Other scenarios not considered here could result in a larger wave (for example, landslides that move because of an earthquake or a sequence of landslides). Finally, our simulations with D-Claw permit seamless simulation of wave initiation by the landslides but they may produce different results than other methods for landslidederived wave initiation (for example, vertical seafloor movement, multilayer models) or application of codes that use different wave models (for example, shallow water versus Boussinesq type). The results presented here emphasize the importance of up-to-date topographic and bathymetric data for identifying, assessing, and simulating the potential hazard of tsunamigenic landslides, particularly in recently deglaciated areas where new subaerial and submarine terrain is being revealed.

\section{Acknowledgments}

We thank Christina Neal and Jonathan Godt for constructive suggestions during modeling and writing of this report. Comments from Eric Geist, James Gridley, Summer Ohlendorf, J. Barrett Salisbury, Janet Slate, Brian Shiro, and Elena Suleimani significantly improved the contents and clarity of the report. Figures and maps presented here used the cmocean Python package (Thyng and others, 2016). 


\section{References Cited}

Alaska Division of Geology \& Geophysical Surveys [DGGS], 2021, Barry Arm Landslide and tsunami hazardAlaska Department of Natural Resources: Geological \& Geophysical Surveys web page, accessed on April 13, 2021, at https://dggs.alaska.gov/hazards/barry-arm-faq.html

Barnhart, K.R., Jones, R.P., George, D.L., Coe, J.A., Staley, D.A., 2021, Select model results from simulations of hypothetical rapid failures of landslides into Barry Arm Fjord, Prince William Sound, Alaska: U.S. Geological Survey data release, https://doi.org/10.5066/P9XVJDNP.

Berger, M.J., George, D.L., LeVeque, R.J., and Mandli, K.T., 2011, The GeoClaw software for depth-averaged flows with adaptive refinement: Advances in Water Resources, v. 34, no. 9, p. 1195-1206, accessed June 17, 2021, at https://doi.org/10.1016/j.advwatres.2011.02.016.

Bessette-Kirton, E., Allstadt, K., Pursley, J., and Godt, J., 2017, Preliminary analysis of satellite imagery and seismic observations of the Nuugaatsiaq landslide and tsunami, Greenland: U.S. Geological Survey web page, accessed April 6, 2021, at https://www.usgs.gov/natural-hazards/ landslide-hazards/science/preliminary-analysis-satelliteimagery-and-seismic

Chen, W.F., 1975, Limit analysis and soil plasticity, v. 7 of Developments in Geotechnical Engineering: Amsterdam, Elsevier, 638 p.

Coe, J.A., Wolken, G.J., Daanen, R.P., and Schmitt, R.G., 2021, Map of landslide structures and kinematic elements at Barry Arm, Alaska in the summer of 2020: U.S. Geological Survey data release, accessed June 17, 2021, at https://doi.org/10.5066/P9EUCGJQ.

Daanen, R.P., Wolken, G.J., Wikstrom Jones, K., and Herbst, A.M., 2021, High resolution lidar-derived elevation data for Barry Arm landslide, southcentral Alaska, June 26, 2020: Alaska Division of Geological \& Geophysical Surveys Raw Data File 2021-3, 9 p., accessed June 17, 2021, at https://doi.org/10.14509/30593.

Dai, C., Higman, B., Lynett, P.J., Jacquemart, M., Howat, I.M., Liljedahl, A.K., Dufresne, A., Freymueller, J.T., Geertsema, M., Ward Jones, M., and Haeussler, P., 2020, Detection and assessment of a large and potentially tsunamigenic periglacial landslide in Barry Arm, Alaska: Geophysical Research Letters, v. 47, no. 22, article e2020GL089800, accessed June 17, 2021, at https://doi.org/10.102 9/2020GL089800.
Das, B., 2020, Principles of Geotechnical Engineering 10th ed.: Stamford, Conn, Cengage Learning, $880 \mathrm{p}$.

Fritz, H.M., Hager, W.H., and Minor, H.-E., 2004, Near field characteristics of landslide generated impulse waves: Journal of Waterway, Port, Coastal, and Ocean Engineering, v. 130, no. 6, p. 287-302, accessed June 17, 2021, at https://doi.org/10.1061/(ASCE)0733950X(2004)130:6(287).

Gauthier, D., Anderson, S.A., Fritz, H.M., and Giachetti, T., 2018, Karrat Fjord (Greenland) tsunamigenic landslide of 17 June 2017-Initial 3D observations: Landslides, v. 15, no. 2, p. 327-332, accessed June 17, 2021, at https://doi.org/ 10.1007/s10346-017-0926-4.

Geist, E.L., Lynett, P.J., and Chaytor, J.D., 2009, Hydrodynamic modeling of tsunamis from the Currituck landslide: Marine Geology, v. 264, no. 1-2, p. 41-52, accessed June 17, 2021, at https://doi.org/10.1016/ j.margeo.2008.09.005.

George, D.L., 2006, Finite volume methods and adaptive refinement for tsunami propagation and inundation: Seattle, Washington, University of Washington, Ph.D. dissertation, 183 p., accessed June 17, 2021, at http://hdl.handle.net/ $1773 / 4639$

George, D.L., and Iverson, R.M., 2014, A depth-averaged debris-flow model that includes the effects of evolving dilatancy-II. Numerical predictions and experimental tests: Proceedings of the Royal Society of London. Series A, v. 470, no. 2170, p. 20130820, accessed June 17, 2021, at https://doi.org/10.1098/rspa.2013.0820.

George, D.L., Iverson, R.M., and Cannon, C.M., 2017, New methodology for computing tsunami generation by subaerial landslides-Application to the 2015 Tyndall Glacier landslide, Alaska: Geophysical Research Letters, v. 44, no. 14, p. 7276-7284, accessed June 17, 2021, at https://doi.org/ 10.1002/2017GL074341.

Grilli, S.T., Harris, J.C., Tajalli Bakhsh, T.S., Masterlark, T.L., Kyriakopoulos, C., Kirby, J.T., and Shi, F., 2013, Numerical simulation of the 2011 Tohoku tsunami based on a new transient FEM co-seismic source - Comparison to far- and near-field observations: Pure and Applied Geophysics, v. 170 , no. $6-8$, p. 1333-1359, accessed June 17, 2021, at https://doi.org/10.1007/s00024-012-0528-y.

Grilli, S.T., and Watts, P., 2005, Tsunami generation by submarine mass failure. Part I-Modeling, experimental validation, sensitivity analysis: Journal of Waterway, Port, Coastal, and Ocean Engineering, v. 131, no. 6, p. 283-297, accessed June 17, 2021, at https://doi.org/10.1061/ (ASCE)0733-950X(2005)131:6(283). 
Haeussler, P.J., Gulick, S.P.S., McCall, N., Walton, M., Reece, R., Larsen, C., Shugar, D.H., Geertsema, J., Venditti, G., and Labay, K., 2018, Submarine deposition of a subaerial landslide in Taan Fiord, Alaska: Journal of Geophysical Research. Earth Surface, v. 123, no. 10, p. 2443-2463, accessed June 17, 2021, at https://doi.org/10.1029/ 2018JF004608.

Heller, V., and Hager, W.H., 2011, Wave types of landslide generated impulse waves: Ocean Engineering, v. 38, no. 4, p. 630-640, accessed June 17, 2021, at https://doi.org/ 10.1016/j.oceaneng.2010.12.010.

Higman, B., Shugar, D.H., Stark, C.P., Ekström, G., Koppes, M.N., Lynett, P.J., Dufresne, A., Haeussler, P.J., Geertsema, M., Gulick, S., Mattox, A., Venditti, J.G., Walton, M.A.L., McCall, N., Mckittrick, E., MacInnes, B., Bilderback, E.L., Tang, H., Willis, M.J., Richmond, B., Reece, R.S., Larsen, C., Olson, B., Capra, J., Ayca, A., Bloom, C., Williams, H., Bonno, D., Weiss, R., Keen, A., Skanavis, V., and Loso, M., 2018, The 2015 landslide and tsunami in Taan Fiord, Alaska: Scientific Reports, v. 8, no. 1, p. 12993, accessed June 17, 2021, at https://doi.org/10.1038/s41598-018-30475-w.

Iverson, R.M., and George, D.L., 2014, A depth-averaged debris-flow model that includes the effects of evolving dilatancy-I. Physical basis: Proceedings of the Royal Society of London. Series A, v. 470, no. 2170, p. 20130819 , accessed June 17, 2021, at https://doi.org/10.1098/ rspa.2013.0819.

Iverson, R.M., and George, D.L., 2016, Modelling landslide liquefaction, mobility bifurcation and the dynamics of the 2014 Oso disaster: Geotechnique, v. 66, no. 3, p. 175-187, accessed June 17, 2021, at https://doi.org/10.1680/ jgeot.15.LM.004.

Iverson, R.M., George, D.L., Allstadt, K., Reid, M.E., Collins, B.D., Vallance, J.W., Schilling, S.P., Godt, J.W., Cannon, C.M., Magirl, C.S., Baum, R.L., Coe, J.A., Schulz, W.H., and Bower, J.B., 2015, Landslide mobility and hazardsImplications of the 2014 Oso disaster: Earth and Planetary Science Letters, v. 412, p. 197-208, accessed June 17, 2021, at https://doi.org/10.1016/j.epsl.2014.12.020.

Johnson, B.L., 1916, Retreat of Barry Glacier, Port Wells, Prince William Sound, Alaska, between 1910 and 1914: U.S. Geological Survey Professional Paper, v. 98-C, p. 35-36, accessed June 17, 2021, at https://doi.org/10.3133/pp98C.

Kirby, J.T., 2016, Boussinesq models and their application to coastal processes across a wide range of scales: Journal of Waterway, Port, Coastal, and Ocean Engineering, v. 142, no. 6, p. 03116005, accessed June 17, 2021, at https://doi.org/10.1061/(ASCE)WW.1943-5460.0000350.
Kirby, J.T., Shi, F., Nicolsky, D., and Misra, S., 2016, The 27 April 1975 Kitimat, British Columbia, submarine landslide tsunami-A comparison of modeling approaches: Landslides, v. 13, no. 6, p. 1421-1434, accessed June 17, 2021, at https://doi.org/10.1007/s10346-016-0682-x.

Kirby, J.T., Shi, F., Tehraninirad, B., Harris, J.C., and Grilli, S.T., 2013, Dispersive tsunami waves in the ocean-Model equations and sensitivity to dispersion and Coriolis effects: Ocean Modelling, v. 62, p. 39-55, accessed June 17, 2021, at https://doi.org/10.1016/j.ocemod.2012.11.009.

LeVeque, R.J., 2002, Finite volume methods for hyperbolic problems - Texts in applied mathematics: Cambridge, Cambridge University Press, 580 p. https://doi.org/10.1017/ CBO9780511791253

LeVeque, R.J., George, D.L., and Berger, M.J., 2011, Tsunami modeling with adaptively refined finite volume methods: Acta Numerica, v. 20, p. 211-289, accessed June 17, 2021, at https://doi.org/10.1017/S0962492911000043.

Løvholt, F., Pedersen, G., Harbitz, C.B., Glimsdal, S., and Kim, J., 2015, On the characteristics of landslide tsunamis: Philosophical Transactions of the Royal Society A., v. 373 , no. 2053, p. 20140376, accessed June 17, 2021, at https://doi.org/10.1098/rsta.2014.0376.

Lynett, P.J., 2006, Nearshore wave modeling with high-order Boussinesq-type equations: Journal of Waterway, Port, Coastal, and Ocean Engineering, v. 132, no. 5, p. 348-357, accessed June 17, 2021, at https://doi.org/10.1061/ (ASCE)0733-950X(2006)132:5(348).

Lynett, P.J., and Liu, P.L.-F., 2002, A numerical study of submarine-landslide-generated waves and run-up: Proceedings of the Royal Society of London. Series A, v. 458 , no. 2028 , p. $2885-2910$, accessed June 17,2021 , at https://doi.org/10.1098/rspa.2002.0973.

Lynett, P.J., and Liu, P.L.-F., 2005, A numerical study of the run-up generated by three-dimensional landslides: Journal of Geophysical Research. Oceans, v. 110, no. C3, C03006, accessed June 17, 2021, at https://doi.org/10.1029/ 2004JC002443.

Ma, G., Kirby, J.T., and Shi, F., 2013, Numerical simulation of tsunami waves generated by deformable submarine landslides: Ocean Modelling, v. 69, p. 146-165, accessed June 17, 2021, at https://doi.org/10.1016/ j.ocemod.2013.07.001.

Mandli, K.T., Ahmadia, A.J., Berger, M.J., Calhoun, D., George, D.L., Hadjimichael, Y., Ketcheson, D.I., Lemoine, G.I., and LeVeque, R.J., 2016, Clawpack-Building an open source ecosystem for solving hyperbolic PDEs: PeerJ. Computer Science, v. 2, p. e68, accessed June 17, 2021, at https://doi.org/10.7717/peerj-cs.68. 
Miller, D.J., 1960a, The Alaska earthquake of July 10, 1958Giant wave in Lituya Bay: Bulletin of the Seismological Society of America, v. 50, no. 2, p. 253-266, accessed June 17, 2021, at https://pubs.geoscienceworld.org/ssa/bssa/ article-pdf/50/2/253/2692623/BSSA0500020253.pdf.

Miller, D.J., 1960b, Giant waves in Lituya Bay Alaska: U.S. Geological Survey Professional Paper 354-C, p. 51-86, 1 sheet, scale 1:50,000, accessed June 17, 2021, at https://pubs.usgs.gov/pp/0354c/report.pdf.

National Oceanic and Atmospheric Administration [NOAA], 1992, Report for H10441: National Oceanic and Atmospheric Administration [NOAA] web page, accessed April 5, 2021, at https://www.ngdc.noaa.gov/nos/H10001H12000/H10441.html.

National Oceanic and Atmospheric Administration [NOAA], 2020, Report for H13396: National Oceanic and Atmospheric Administration [NOAA] web page, accessed April 5, 2021, at https://www.ngdc.noaa.gov/nos/H12001H14000/H13396.html.

National Oceanic and Atmospheric Administration [NOAA] National Geophysical Data Center, 2009a, Prince William Sound, Alaska 8 arc-second MHHW coastal digital elevation model: National Oceanic and Atmospheric Administration [NOAA], National Centers for Environmental Information web page, accessed April 5, 2021, at https://data.noaa.gov/metaview/page?xml=NOAA/ NESDIS/NGDC/MGG/DEM//iso/xml/638.xml\&view= getDataView\&header=none.

National Oceanic and Atmospheric Administration [NOAA] National Geophysical Data Center, 2009b, Whittier, Alaska 8/15 arc-second MHHW coastal digital elevation model: National Oceanic and Atmospheric Administration [NOAA], National Centers for Environmental Information web page, accessed April 5, 2021, at https://www.ncei .noaa.gov/access/metadata/landing-page/bin/iso?id=gov.n oaa.ngdc.mgg.dem:530.

Poli, P., 2017, Creep and slip-Seismic precursors to the Nuugaatsiaq landslide (Greenland): Geophysical Research Letters, v. 44, no. 17, p. 8832-8836, accessed June 17, 2021, at https://doi.org/10.1002/2017GL075039.

Randolph Glacier Inventory Consortium [RGI Consortium], 2017, Randolph Glacier Inventory-A dataset of global glacier outlines (ver. 6.0): Boulder, Colorado, Global Land Ice Measurements from Space [GLIMS] technical report, accessed June 17, 2021, at https://doi.org/10.7265/ N5-RGI-60.

Reid, M.E., Christian, S.B., and Brien, D.L., 2000, Gravitational stability of three-dimensional stratovolcano edifices-Journal of Geophysical Research B: Solid Earth and Planets, v. 105, no. 3, p. 6042-6056, accessed June 17, 2021, at https://doi.org/10.1029/1999JB900310.
Reid, M.E., Christian, S.B., Brien, D.L., and Henderson, S.T., 2015, Scoops3D - Software to analyze three-dimensional slope stability throughout a digital landscape: U.S. Geological Survey Techniques and Methods, book 14, chap. A1, 218 p, accessed June 17, 2021, at https://doi.org/10.3133/tm14A1.

Rocha, F.M., Johnson, C.G., and Gray, J.M.N.T., 2019, Self-channelisation and levee formation in monodisperse granular flows: Journal of Fluid Mechanics, v. 876, p. 591-641, accessed June 17, 2021, at https://doi.org/ 10.1017/jfm.2019.518.

Schaefer, L.N., Coe, J.A., Godt, J.W., and Wolken, G.J., 2020, Interferometric synthetic aperture radar data from 2020 for landslides at Barry Arm Fjord, Alaska (ver. 1.4, November 2020): U.S. Geological Survey data release, accessed June 17, 2021, at https://doi.org/10.5066/P9Z0 4 LNK.

Shi, F., Kirby, J.T., Harris, J.C., Geiman, J.D., and Grilli, S.T., 2012, A high-order adaptive time-stepping TVD solver for Boussinesq modeling of breaking waves and coastal inundation: Ocean Modelling, v. 43-44, p. 36-51, accessed June 17, 2021, at https://doi.org/10.1016/ j.ocemod.2011.12.004.

Sraj, I., Mandli, K.T., Knio, O.M., Dawson, C.N., and Hoteit, I., 2014, Uncertainty quantification and inference of Manning's friction coefficients using DART buoy data during the Tōhoku tsunami: Ocean Modelling, v. 83, p. 82-97, accessed June 17, 2021, at https://doi.org/10.1016/ j.ocemod.2014.09.001.

Thyng, K.M., Greene, C.A., Hetland, R.D., Zimmerle, H.M., and DiMarco, S.F., 2016, True colors of oceanographyGuidelines for effective and accurate colormap selection: Washington, D.C., Oceanography, v. 29, no. 3, p. 9-13, accessed June 17, 2021, at https://doi.org/10.5670/ oceanog.2016.66.

U.S. Geological Survey Advanced Research Computing, 2021, USGS Denali supercomputer: U.S. Geological Survey [USGS] web page, accessed June 17, 2021, at https://doi.org/10.5066/P9PSW367.

Walder, J.S., Watts, P., Sorensen, O.E., and Janssen, K., 2003, Tsunamis generated by subaerial mass flows: Journal of Geophysical Research: Solid Earth, v. 108, no. B5, 19 p, accessed June 17, 2021, at https://doi.org/10.1029/ 2001JB000707.

Ward, S.N., and Day, S., 2010, The 1958 Lituya Bay landslide and tsunami-A tsunami ball approach: Journal of Earthquake and Tsunami, v. 4, no. 04, p. 285-319, accessed June 17, 2021, at https://doi.org/10.1142/ S1793431110000893. 
Watts, P., Grilli, S.T., Kirby, J.T., Fryer, G.J., and Tappin, D.R., 2003, Landslide tsunami case studies using a Boussinesq model and a fully nonlinear tsunami generation model: Natural Hazards and Earth System Sciences, v. 3, no. 5, p. 391-402, accessed June 17, 2021, at https://doi.org/ 10.5194/nhess-3-391-2003.

Wieczorek, G.F., Geist, E.L., Motyka, R.J., and Jakob, M., 2007, Hazard assessment of the Tidal Inlet landslide and potential subsequent tsunami, Glacier Bay National Park, Alaska: Landslides, v. 4, no. 3, p. 205-215, accessed June 17, 2021, at https://doi.org/10.1007/s10346-007-0084-1.

World Data Service, National Geophysical Data Center, 2020, NCEI/WDS Global Historical Tsunami Database: National Oceanic and Atmospheric Administration [NOAA], National Centers for Environmental Information online database, accessed April 14, 2021, at https://doi.org/ 10.7289/V5PN93H7.

Yavari-Ramshe, S., and Ataie-Ashtiani, B., 2016, Numerical modeling of subaerial and submarine landslide-generated tsunami waves - Recent advances and future challenges: Landslides, v. 13, no. 6, p. 1325-1368, accessed June 17, 2021, at https://doi.org/10.1007/s10346-016-0734-2.

Zhou, H., and Teng, M.H., 2010, Extended fourth-order depthintegrated model for water waves and currents generated by submarine landslides: Journal of Engineering Mechanics, v. 136, no. 4, p. 506-516, accessed June 17, 2021, at https://doi.org/10.1061/(ASCE)EM.1943-7889.0000087. 
Denver Publishing Service Center

For more information concerning the research in this report, contact the

Center Director, USGS Geologic Hazards Science Center

Box 25046, Mail Stop 966

Denver, CO 80225

(303) 273-8579

Or visit Geologic Hazards Science Center website at https://www.usgs.gov/centers/geohazards 
